LBNL-50451

\title{
Inclusion of Cool Roofs in Nonresidential Title 24 Prescriptive Requirements
}

\author{
Ronnen Levinson, Hashem Akbari, Steve Konopacki, and Sarah Bretz \\ Heat Island Group \\ Environmental Energy Technologies Division \\ Lawrence Berkeley National Laboratory \\ Berkeley, CA 94720
}

December 2002

This project was supported by the Pacific Gas and Electric Company through a grant to Lawrence Berkeley National Laboratory via the California Institute for Energy Efficiency. It was also supported by the Assistant Secretary for Energy Efficiency and Renewable Energy (U.S. Department of Energy) under contract No. DE-AC03-76SF00098. 



\title{
Inclusion of Cool Roofs in Nonresidential Title 24 Prescriptive Requirements
}

\author{
Ronnen Levinson, Hashem Akbari, Steve Konopacki, and Sarah Bretz \\ Heat Island Group \\ Environmental Energy Technologies Division \\ Lawrence Berkeley National Laboratory \\ Berkeley, CA 94720
}

\begin{abstract}
Roofs that have high solar reflectance (high ability to reflect sunlight) and high thermal emittance (high ability to radiate heat) tend to stay cool in the sun. The same is true of low-emittance roofs with exceptionally high solar reflectance. Substituting a cool roof for a noncool roof tends to decrease cooling electricity use, cooling power demand, and cooling-equipment capacity requirements, while slightly increasing heating energy consumption. Cool roofs can also lower the ambient air temperature in summer, slowing ozone formation and increasing human comfort.
\end{abstract}

DOE-2.1E building energy simulations indicate that use of a cool roofing material on a prototypical California nonresidential building with a low-sloped roof yields average annual cooling energy savings of approximately $300 \mathrm{kWh} / 1000 \mathrm{ft}^{2}$ [3.2 kWh/m²], average annual natural gas deficits of 4.9 therm/1000 ft2 [5.6 MJ/m²], average source energy savings of $2.6 \mathrm{MBTU} / 1000 \mathrm{ft}^{2}\left[30 \mathrm{MJ} / \mathrm{m}^{2}\right]$, and average peak power demand savings of $0.19 \mathrm{~kW} / 1000 \mathrm{ft}^{2}\left[2.1 \mathrm{~W} / \mathrm{m}^{2}\right]$. The 15-year net present value (NPV) of energy savings averages $\$ 450 / 1000 \mathrm{ft}^{2}\left[\$ 4.90 / \mathrm{m}^{2}\right]$ with time dependent valuation (TDV), and $\$ 370 / 1000 \mathrm{ft}^{2}\left[\$ 4.00 / \mathrm{m}^{2}\right]$ without TDV. When cost savings from downsizing cooling equipment are included, the average total savings (15-year NPV + equipment savings) rises to $\$ 550 / 1000 \mathrm{ft}^{2}\left[\$ 5.90 / \mathrm{m}^{2}\right]$ with TDV, and to $\$ 470 / 1000 \mathrm{ft}^{2}\left[\$ 5.00 / \mathrm{m}^{2}\right]$ without TDV.

Total savings range from 0.18 to $0.77 \$ / \mathrm{ft}^{2}$ [1.90 to $8.30 \$ / \mathrm{m}^{2}$ ] with TDV, and from 0.16 to $0.66 \$ / \mathrm{ft}^{2}$ [1.70 to $7.10 \$ / \mathrm{m}^{2}$ ] without TDV, across California's 16 climate zones. The typical cost premium for a cool roof is 0.00 to $0.20 \$ / \mathrm{ft}^{2}$ [0.00 to $2.20 \$ / \mathrm{m}^{2}$ ]. Cool roofs with premiums up to $\$ 0.20 / \mathrm{ft}^{2}\left[\$ 2.20 / \mathrm{m}^{2}\right]$ are expected to be cost effective in climate zones 2 through 16; those with premiums not exceeding $\$ 0.18 / \mathrm{ft}^{2}\left[\$ 1.90 / \mathrm{m}^{2}\right]$ are expected to be also cost effective in climate zone 1 . Hence, this study recommends that the year-2005 California building energy efficiency code (Title 24, Part 6 of the California Code of Regulations) for nonresidential buildings with low-sloped roofs include a cool-roof prescriptive requirement in all California climate zones. Buildings with roofs that do not meet prescriptive requirements may comply with the code via an "overall-envelope" approach (non-metal roofs only), or via a performance approach (all roof types). 



\section{Acknowledgments}

This project was supported by the Pacific Gas and Electric Company (PG\&E) through a grant to Lawrence Berkeley National Laboratory (LBNL) via the California Institute for Energy Efficiency (CIEE). It was also supported by the Assistant Secretary for Energy Efficiency and Renewable Energy (U.S. Department of Energy) under contract No. DE-AC03-76SF00098. We acknowledge the support and guidance of Misti Bruceri, Patrick Eilert, Gary Fernstrom, and Peter Turnbull of PG\&E; Charles Eley of Eley Associates; Bill Pennington, Bryan Alcorn, and Elaine Hebert of the California Energy Commission; Jon McHugh of the Heschong Mahone Group; Carl Blumstein of the CIEE; Jeffrey Johnson of the New Buildings Institute; and Roger Wright and Ramona Peet of RLW Analytics. 



\section{Table of Contents}

Abstract

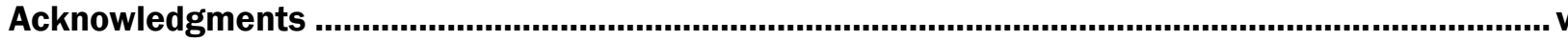

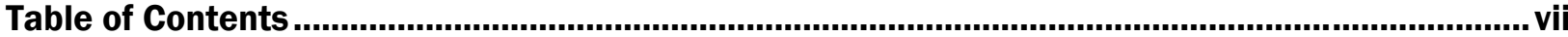

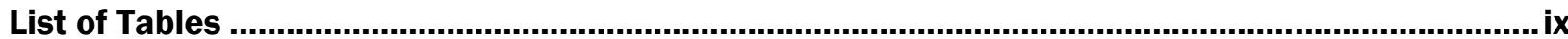

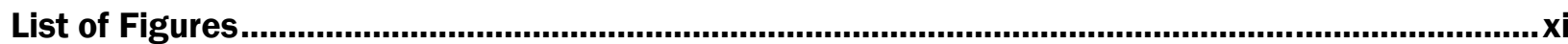

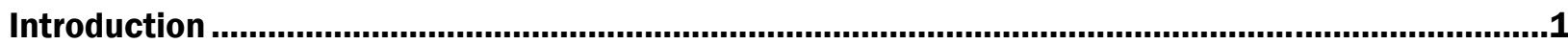

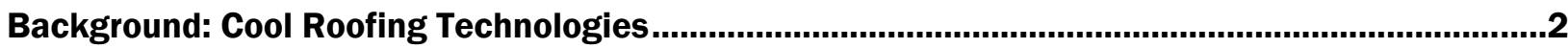

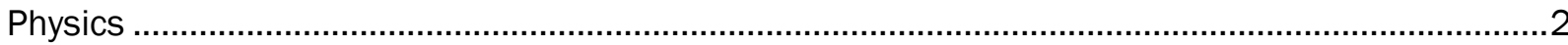

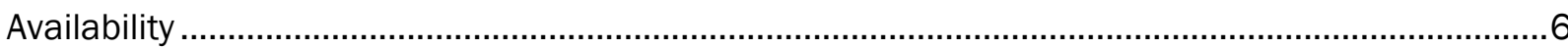

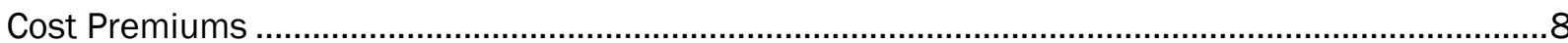

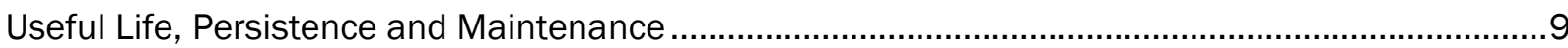

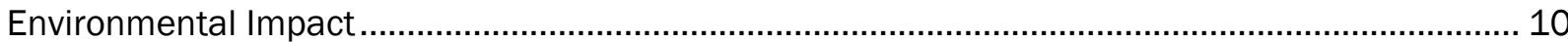

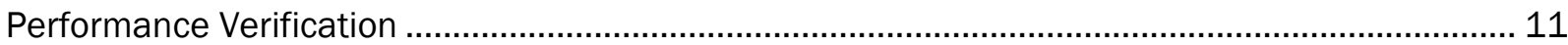

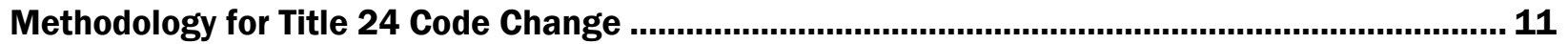

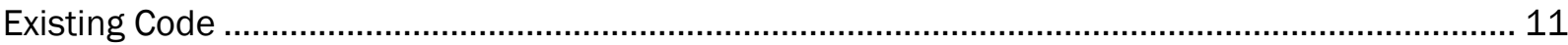

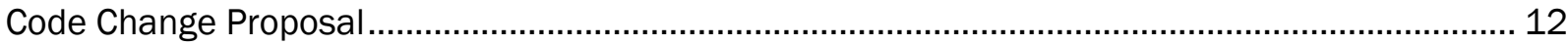

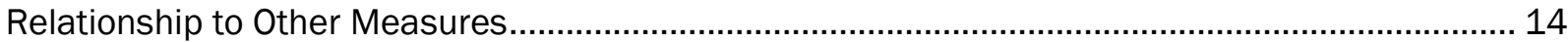

Cost Effectiveness Analysis of Code Change ................................................................................... 15

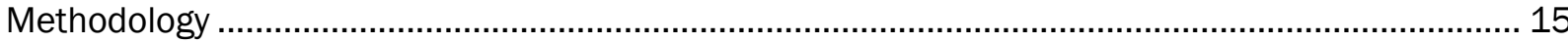

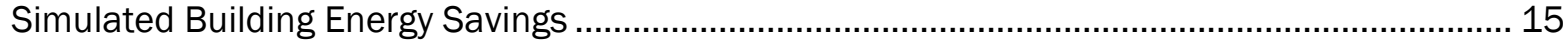

Projected Statewide Energy Savings for Nonresidential New Construction ............................... 19

Measured Building Energy Savings ........................................................................................ 19

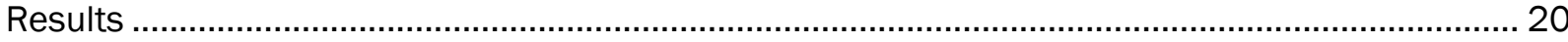

Simulated Building Energy Savings for New Construction ......................................................... 20

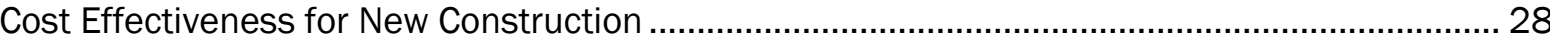

Statewide Projected Savings for New Construction .................................................................. 28

Statewide Projected Savings for Roof Replacement .................................................................... 29

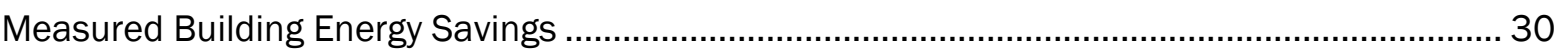

Summary and Conclusions ............................................................................................................... 33

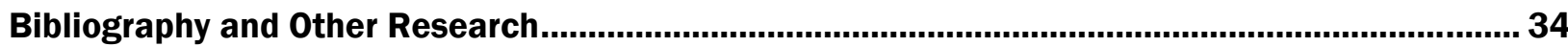

Appendix A: Requisite Reflectance Premium for a Low-Emittance Cool Roof............................... 41

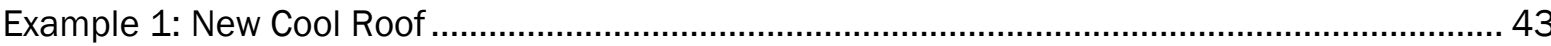




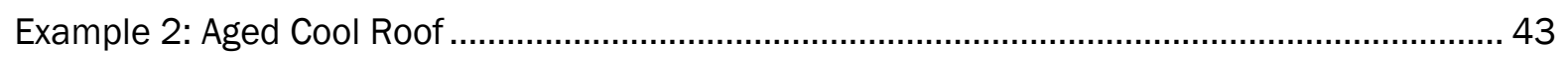

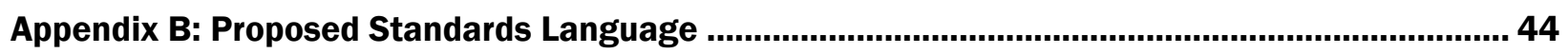

Proposed Changes to 2001 California Energy Efficiency Standards for Residential and

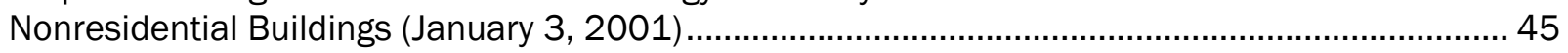

Section 101 - Definitions and Rules of Construction ............................................................. 45

Section 118 - Mandatory Requirements for Insulation and Cool Roofs ..................................... 45

Section 143 - Prescriptive Requirements for Building Envelopes.............................................. 46

Section 149 - Additions, Alterations, and Repairs to Existing Buildings That Will Be Nonresidential, High-Rise Residential, and Motel/Hotel Occupancies ........................................ 48

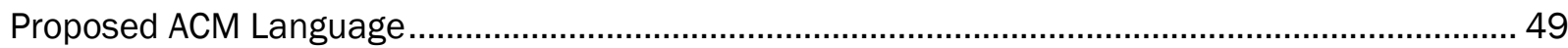

Nonresidential Alternative Calculation Approval Method .......................................................... 49 


\section{List of Tables}

Table 1. Cool and noncool options for low-sloped roofs...................................................................

Table 2. Nonresidential-building low-sloped roofing technologies and their market shares.................4

Table 3. Leading roofing product manufacturers ................................................................................ 7

Table 4. Cost premiums for cool varieties of common low-sloped roofing products..............................8

Table 5. Characteristics of a prototypical Title 24 small office building .............................................. 17

Table 6. Life expectancies of roofing materials ................................................................................. 18

Table 7. Simulated cool-roof savings for a prototypical Title 24 small office building ........................ 20

Table 8. Daytime-conditioned nonresidential roof area and statewide savings per unit roof area..... 29

Table 9. Statewide annual nonresidential new construction floor area and savings.......................... 30

Table 10. Measured energy savings in six California nonresidential buildings .................................. 32 



\section{List of Figures}

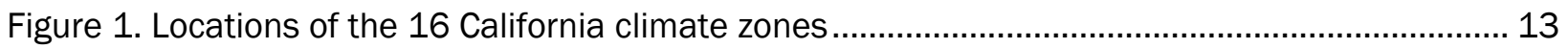

Figure 2. Annual electricity savings $\left(\mathrm{kWh} / 1000 \mathrm{ft}^{2}\right)$ by climate zone .............................................. 22

Figure 3. Annual natural gas deficit (therms/1000 ft²) by climate zone ......................................... 23

Figure 4. Annual source energy savings (MBTU/1000 ft²) by climate zone ..................................... 24

Figure 5. Annual peak electric power demand reduction $\left(\mathrm{kW} / 1000 \mathrm{ft}^{2}\right)$ by climate zone................... 25

Figure 6. 15-year net present value (NPV) of energy savings $\left(\$ / 1000 \mathrm{ft}^{2}\right)$ by climate zone .............. 26

Figure 7. Total savings (equipment + NPV energy) in $\$ / 1000 \mathrm{ft}^{2}$ by climate zone ............................ 27 



\section{Introduction}

Roofs that have high solar reflectance (high ability to reflect sunlight) and high thermal emittance (high ability to radiate heat) tend to stay cool in the sun. The same is true of low-emittance roofs with exceptionally high solar reflectance. ${ }^{1}$ Roofs that stay cool in the sun are hereafter denoted "cool roofs."

Low roof temperatures lessen the flow of heat from the roof into the building, reducing the need for electricity for space cooling in conditioned buildings. Since roof temperatures peak in late afternoon, when summer electricity use is highest, cool roofs can also reduce peak electricity demand. Prior research has indicated that savings are greatest for buildings located in climates with long cooling seasons and short heating seasons, particularly those buildings that have distribution ducts in the plenum, cool-coatable distribution ducts on the roof, and/or low rates of plenum ventilation (Akbari et al. 1999; Konopacki and Akbari 1998).

Cool roofs transfer less heat to the outdoor environment than do warm roofs. The resulting lower outside air temperatures can slow urban smog formation and increase human health and outdoor comfort. Reduced thermal stress may also increase the lifetime of cool roofs, lessening maintenance and waste (Akbari et al. 2001).

This report details a proposal to promote the use of cool roofs to reduce cooling energy usage and peak electrical power demand in air-conditioned buildings. The measure would modify the treatment of cool roofs in California's building energy efficiency standards (Title 24, Part 6 of the California Code of Regulations, hereafter denoted as "Title 24") for nonresidential (NR) buildings, including but not limited to offices, retail stores, health care facilities, schools, universities, and high-tech manufacturing facilities. Under the current standards, cool roofs are a compliance option. Under this proposal, cool roofs would be considered a prescriptive requirement for NR buildings with low-sloped roofs (i.e., roofs with a ratio of rise to run not exceeding 2:12). Prescriptive requirements would not change for NR buildings with high-sloped roofs, high-rise residential buildings, low-rise residential buildings, or hotel/motel buildings.

\footnotetext{
${ }^{1} \mathrm{~A}$ low-emittance roof with exceptionally high solar reflectance can stay as cool as a white roof. For example, a new bare metal roof with a thermal emittance of 0.20 and a solar reflectance of 0.79 would under standard conditions (i.e., specified values of insolation, wind speed, air temperature, and sky temperature) have the same surface temperature as a new white roof with a thermal emittance of 0.75 and a solar reflectance of 0.70. An even higher initial reflectance (in this case, 0.89 ) would be needed to match the surface temperature of the aged low-emittance roof to that of the aged high-emittance cool roof (see Appendix A, p.41).
} 
This study addresses the physics, availability, market, marginal cost, environmental impact, durability, and performance verification of cool roofing technologies, then compares simulated coolroof energy savings to cool-roof cost premiums to estimate the cost effectiveness of cool roofing in each of California's climate zones.

Note: the terms "code" and "standard" will be used interchangeably to refer to Title 24 requirements.

\section{Background: Cool Roofing Technologies}

\section{Physics}

The daytime surface temperature of a roof is raised by absorption of solar radiation and lowered by emission of thermal radiation to the sky. Solar heating is proportional to solar absorptance (absorptance $=1$ - reflectance of an opaque material), while radiative cooling is proportional to thermal emittance. Hence, other factors (e.g., incident solar radiation, convective cooling, and conductive cooling) being equal, a roof with high solar reflectance and high thermal emittance can stay cooler than a roof with a low solar reflectance and/or low thermal emittance.

Virtually all construction materials except shiny, bare metals have high thermal emittance. ${ }^{2}$ Since 95\% of solar radiation arrives at the Earth's surface in the visible and near-infrared (NIR) spectra, ${ }^{3}$ a roof with a non-metallic surface and high visible and/or NIR reflectance will be cool. White surfaces are cool because they have high visible reflectance, high NIR reflectance, and high thermal emittance. Black surfaces are warm because they have low visible and NIR reflectances. ${ }^{4}$ Shiny metals typically have high visible and NIR reflectances, but low thermal emittances, and thus stay warmer than a non-metallic surface of comparable solar reflectance. However, a low-emittance surface can stay as cool as a high-emittance surface if the low-emittance surface has a significantly higher solar reflectance (see Appendix A, p.41). For brevity, the terms reflectance $(\rho)$, absorptance

\footnotetext{
2 Non-metallic construction materials typically have thermal emittances in the range of 0.80 to 0.95 . A bare, shiny metal (e.g., aluminum foil) may have an emittance as low as 0.03 , while a roof coating formed with metal flakes may have an intermediate emittance (circa 0.5 ).

$343 \%$ of the energy in the standard air-mass 1.5 hemispherical solar spectrum $(300-2,500 \mathrm{~nm})$ lies in the visible range $(400-700 \mathrm{~nm})$. Another $52 \%$ is in the near-infrared $(700-2,500 \mathrm{~nm})$, and $5 \%$ in the ultraviolet (300-400 nm).

${ }^{4}$ Some novel black coatings have high NIR reflectance, and thus stay cooler than conventional black surfaces.
} 
$(\alpha)$, and emittance $(\varepsilon)$ will be used hereafter to denote solar reflectance, solar absorptance, and thermal emittance, respectively.

There are cool and noncool options available for nearly all low-sloped roofing products (Table 1). For example, a built-up roof can have an initial reflectance of 0.04 if covered with a smooth, black asphalt surface ( $\varepsilon=0.90$ ), or 0.80 if smooth and coated white ( $\varepsilon=0.90$ ). Similarly, a single-ply membrane can have an initial reflectance of 0.04 if black ( $\varepsilon=0.90), 0.20$ if gray $(\varepsilon=0.90)$, or 0.80 if white ( $\varepsilon=0.90$ ). Low-sloped roofing technologies are described in Table 2.

Table 1. Cool and noncool options for low-sloped roofs. Shown are ranges of typical values for initial solar reflectance, initial thermal emittance, and cost.

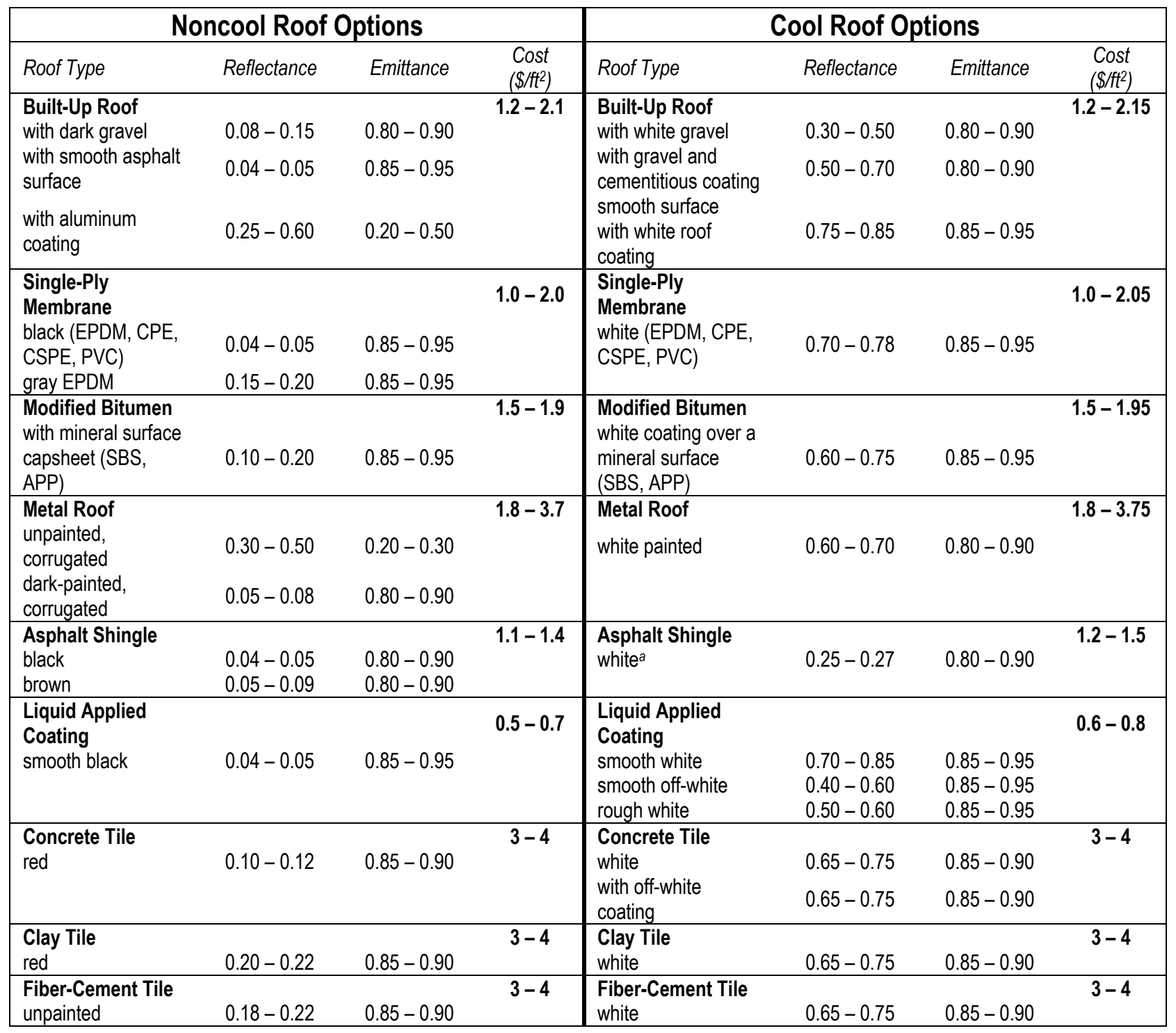

a. Asphalt shingles marketed as "white" are gray, and are not particularly cool. 
Table 2. Nonresidential-building low-sloped roofing technologies and their market shares in three Pacific-region states (NRCA 2000) and 14 western-region states (Dodson 2001).

\begin{tabular}{|c|c|c|c|c|c|c|}
\hline \multirow[b]{2}{*}{ Technology } & \multirow[b]{2}{*}{ Description } & \multirow[b]{2}{*}{$\begin{array}{l}\text { Costa } \\
\left(\$ / \mathrm{ft}^{2}\right)\end{array}$} & \multicolumn{2}{|c|}{$\underline{\mathrm{PACIFIC}}^{b}$} & \multicolumn{2}{|c|}{$\underline{\text { WESTERN }}$} \\
\hline & & & $\begin{array}{l}\text { New } \\
\text { Sales }\end{array}$ & $\begin{array}{l}\text { Retrofit } \\
\text { Sales }\end{array}$ & Sales & Area $^{d}$ \\
\hline $\begin{array}{l}\text { Built-Up } \\
\text { Roof } \\
\text { (BUR) }\end{array}$ & $\begin{array}{l}\text { A continuous, semi-flexible multi-ply roof membrane, consisting of plies (layers) } \\
\text { of saturated felts, coated felts, fabric, or mats, between which alternate layers } \\
\text { of bitumen are applied. (Bitumen is a tarlike hydrocarbon mixture often } \\
\text { including nonmetallic hydrocarbon derivatives; it may be obtained naturally or } \\
\text { from the residue of heat-refining natural substances such as petroleum.) Built- } \\
\text { up roof membranes are typically surfaced with roof aggregate and bitumen, a } \\
\text { liquid-applied coating, or a granule-surfaced cap sheet. }\end{array}$ & 1.7 & $46 \%$ & $52 \%$ & $31 \%$ & $27 \%$ \\
\hline $\begin{array}{l}\text { Modified } \\
\text { Bitumen }\end{array}$ & $\begin{array}{l}\text { (1) A bitumen modified through the inclusion of one or more polymers (e.g., } \\
\text { atactic polypropylene and/or styrene butadiene styrene). } \\
\text { (2) Composite sheets consisting of a polymer-modified bitumen often } \\
\text { reinforced and sometimes surfaced with various types of mats, films, foils, and } \\
\text { mineral granules. It can be classified into two categories: thermoset, and } \\
\text { thermoplastic. A thermoset material solidifies or sets irreversibly when heated; } \\
\text { this property is usually associated with cross-linking of the molecules induced } \\
\text { by heat or radiation. A thermoplastic material softens when heated and } \\
\text { hardens when cooled; this process can be repeated provided that the material } \\
\text { is not heated above the point at which decomposition occurs. }\end{array}$ & 1.7 & $10 \%$ & $15 \%$ & $30 \%$ & $26 \%$ \\
\hline \multirow[t]{2}{*}{ Examples } & $\begin{array}{l}\text { Styrene-butadiene styrene (SBS) is an elastomeric modifier containing high } \\
\text { molecular weight polymers with both thermoset and thermoplastic properties. It } \\
\text { is formed by the block copolymerization of styrene and butadiene monomers. } \\
\text { These polymers are used as modifying compounds in SBS-polymer-modified } \\
\text { asphalt-roofing membranes to impart rubber-like qualities to the asphalt. }\end{array}$ & & $7.5 \%$ & $6.2 \%$ & $13 \%$ & \\
\hline & $\begin{array}{l}\text { Atactic polypropylene (APP) is a thermoplastic modifier containing a group of } \\
\text { high molecular weight polymers formed by the polymerization of propylene. } \\
\text { Used in modified bitumen as a plastic additive to permit heat fusing (torching). }\end{array}$ & & $2.8 \%$ & $8.4 \%$ & $17 \%$ & \\
\hline $\begin{array}{l}\text { Single-Ply } \\
\text { Membrane }\end{array}$ & $\begin{array}{l}\text { A roofing membrane having only one layer of membrane material (either } \\
\text { homogeneous or composite) rather than multiple layers. The principal roof } \\
\text { covering is usually a single-layer flexible membrane, often of thermoset, } \\
\text { thermoplastic, or polymer-modified bituminous compounds. Roofing } \\
\text { membranes can be torch-applied or hot-mopped with asphalt during } \\
\text { application. }\end{array}$ & 1.5 & $18 \%$ & $16 \%$ & $23 \%$ & $22 \%$ \\
\hline \multirow[t]{3}{*}{ Examples } & $\begin{array}{l}\text { Ethylene-propylene-diene monomer (EPDM) is the ASTM-designated name for } \\
\text { an elastomeric single-ply roofing membrane containing a terpolymer of } \\
\text { ethylene, propylene, and diene. EPDM is a thermosetting synthetic } \\
\text { elastomer-that is, a macromolecular material that returns to its approximate } \\
\text { initial dimensions and shape after substantial deformation by a weak stress } \\
\text { and the subsequent release of that stress. }\end{array}$ & & $1.2 \%$ & $0.4 \%$ & $9.0 \%$ & \\
\hline & $\begin{array}{l}\text { Polyvinyl chloride (PVC) is a synthetic thermoplastic polymer prepared from } \\
\text { vinyl chloride. PVC can be compounded into flexible and rigid forms through } \\
\text { the use of plasticizers, stabilizers, fillers, and other modifiers. Flexible forms } \\
\text { are used in the manufacture of sheeting and roof membrane materials. }\end{array}$ & & 6.0 & $5.4 \%$ & $6.3 \%$ & \\
\hline & $\begin{array}{l}\text { Thermoplastic olefin (TPO) is a blend of polypropylene and ethylene-propylene } \\
\text { polymers. Colorants, flame-retardants, UV absorbers, and other proprietary } \\
\text { substances may be blended with TPO to achieve the desired physical } \\
\text { properties. The membrane may or may not be reinforced. }\end{array}$ & & $5.6 \%$ & $5.1 \%$ & $6.3 \%$ & \\
\hline
\end{tabular}




\begin{tabular}{|c|c|c|c|c|c|c|}
\hline & $\begin{array}{l}\text { Chlorosulfonated polyethylene (CSPE) is a synthetic, rubber-like thermoset } \\
\text { material, based on high-molecular-weight polyethylene with sulphonyl chloride, } \\
\text { that is usually formulated to produce a self-vulcanizing membrane. It is best } \\
\text { known by the DuPont trade name Hypalon }{ }^{\mathrm{TM}} \text {. }\end{array}$ & & $0.3 \%$ & $0.3 \%$ & $1.0 \%$ & \\
\hline Metal & Metal roofs can be classified as architectural or structural. & 2.7 & $2.2 \%$ & $1.7 \%$ & $5.2 \%$ & $2.8 \%$ \\
\hline \multirow[t]{2}{*}{ Examples } & $\begin{array}{l}\text { Architectural (hydrokinetic-watershedding) standing-seam roof systems are } \\
\text { typically used on steep slopes with relatively short panel lengths. They usually } \\
\text { do not have sealant in the seam because they are designed to shed water } \\
\text { rapidly. They do not provide structural capacity or load resistance, and their } \\
\text { installation is less labor-intensive because they have a solid substrate platform } \\
\text { that makes installation easier. }\end{array}$ & & $1.6 \%$ & $1.2 \%$ & $2.8 \%$ & \\
\hline & $\begin{array}{l}\text { Structural (hydrostatic-watershedding) standing-seam roof systems are } \\
\text { versatile metal panel systems that can be used on both steep-and low-slope } \\
\text { roofs and are designed to be water-resistant. Most structural standing-seam } \\
\text { systems include a factory-applied sealant in the standing seams to help ensure } \\
\text { water tightness. These panel systems provide structural capacity and load } \\
\text { resistance. }\end{array}$ & & $0.6 \%$ & $0.5 \%$ & $2.4 \%$ & \\
\hline $\begin{array}{l}\text { Asphalt } \\
\text { Shingle }\end{array}$ & $\begin{array}{l}\text { Asphalt is a dark brown to black cementitious material, solid or semisolid, in } \\
\text { which the predominant constituents are naturally-occurring or petroleum- } \\
\text { derived bitumens. It is used as a weatherproofing agent. The term asphalt } \\
\text { shingle is generically used for both fiberglass and organic shingles. There are } \\
\text { two grades of asphalt shingles: (1) standard, a.k.a. 3-tab; and (2) architectural, } \\
\text { a.k.a. laminated or dimensional. Shingles come in various colors. }\end{array}$ & 1.3 & $5.8 \%$ & $2.5 \%$ & $3.6 \%$ & $4.2 \%$ \\
\hline \multirow[t]{2}{*}{ Examples } & $\begin{array}{l}\text { Fiberglass shingles, commonly known as "asphalt shingles," consist of fiber } \\
\text { mats that are coated with asphalt and then covered with granules. Granules, } \\
\text { a.k.a. mineral granules or ceramic granules, are opaque, naturally- or } \\
\text { synthetically-colored aggregates commonly used to surface cap sheets and } \\
\text { shingles. }\end{array}$ & & $5.8 \%$ & $2.4 \%$ & $3.6 \%$ & \\
\hline & $\begin{array}{l}\text { Organic shingles have a thick cellulose base that is saturated in soft asphalt. } \\
\text { This saturation makes them heavier than fiberglass shingles, and less resistant } \\
\text { to heat and humidity, but more durable in freezing conditions. }\end{array}$ & & - & $0.1 \%$ & n/a & \\
\hline Tile & $\begin{array}{l}\text { Usually made of concrete or clay, tile is a combination of sand, cement, and } \\
\text { water; the water fraction depends on the manufacturing process. Fibers may } \\
\text { be added (replacing sand) to increase strength and reduce weight. Concrete } \\
\text { tiles are either air-cured or auto-claved, whereas clay tiles are kiln-fired. Color } \\
\text { is added to the surface of the tile with a slurry coating process, or added to the } \\
\text { mixture during the manufacturing process. }\end{array}$ & 3.5 & $2.5 \%$ & $3.9 \%$ & $0.3 \%$ & $0.1 \%$ \\
\hline $\begin{array}{l}\text { Poly- } \\
\text { urethane } \\
\text { Foam } \\
\text { (SPF) }\end{array}$ & $\begin{array}{l}\text { A foamed plastic material, formed by spraying polymeric methyl diisocyanate } \\
{[\mathrm{PMDI}] \text { and a resin to form a rigid, fully adhered, water-resistant, and insulating }} \\
\text { membrane. }\end{array}$ & 0.7 & $0.4 \%$ & $6.3 \%$ & $2.5 \%$ & $5.2 \%$ \\
\hline $\begin{array}{l}\text { Liquid } \\
\text { Applied } \\
\text { Coatings }\end{array}$ & $\begin{array}{l}\text { A liquid surfacing material (acrylic, elastomeric, or asphaltic) for various roof } \\
\text { types, especially BUR and metal. Available in different colors; may be divided } \\
\text { on the basis of reflectivity into black, aluminum, white, and tinted coatings. }\end{array}$ & 0.4 & $3.2 \%$ & $3.3 \%$ & $2.5 \%$ & $9.2 \%$ \\
\hline Other & $\begin{array}{l}\text { All other roofing materials that are not covered under the categories mentioned } \\
\text { above. }\end{array}$ & 1 & & & $2.1 \%$ & $3.1 \%$ \\
\hline
\end{tabular}

a. LBNL's numbers for typical material and labor costs are approximate, and are based on phone interviews.

b. The NRCA's estimates of Pacific-region market distributions may lack statistical validity because fewer than 50 contractors from these three states (CA, OR, and WA) responded to its survey.

c. California accounts for $38 \%$ of the market in the 14 states (AK, AZ, CA, CO, HI, ID, MT, NV, NM, OR, TX, UT, WA, and WY) that make up the western region surveyed by Western Roofing magazine.

d. LBNL's estimates of roof areas fractions are derived from product market shares and costs. 


\section{Availability}

Western Roofing Insulation and Siding magazine reported that in the year 2001, three productsbuilt-up roofing (BUR), modified bitumen, and single-ply membrane-accounted for $83 \%$ of sales dollars (material and labor) in the $\$ 6.0 B$ (billion), 14-state western U.S. market ${ }^{5}$ for low-sloped nonresidential-building roofing (Dodson 2001). Metal, asphalt shingle, tile, polyurethane foam, liquid applied coatings, and other materials made up the remainder. California represented about 38\% of the western market-i.e., \$2.3B. Product shares in the western-region roofing market are not necessarily representative of those in California.

An earlier study by Western Roofing Insulation and Siding (Dodson 1999) reported that in the year 1999, the values of the western-region nonresidential replacement and new roofing markets were $\$ 4.1 B$ and $\$ 1.4 B$, respectively. Since the 2001 study did not separate replacement roofing from new roofing, the 1999 ratio of $\$ 4$.1B replacement to $\$ 1.4 \mathrm{~B}$ new will be used to compare the sizes of the two markets. By this metric, the replacement market is 2.9 times the size of the new construction market.

The National Roofing Contractors Association (NRCA) reported that the year-2000 low-sloped roofing market in the Pacific region-California, Oregon, and Washington-was dominated by BUR, modified bitumen, and single-ply membrane, making up $74 \%$ of new-construction sales dollars and $83 \%$ of reroofing sales dollars (NRCA 2000). However, the 2000 NRCA estimate of Pacific-region BUR sales fraction was much higher than the 2001 Western Roofing estimate of BUR sales fraction in the western region ( $50 \%$ vs. $29 \%$ ), while the reverse was true for modified bitumen ( $12 \%$ vs. $30 \%$ ). The NRCA's Pacific-region figures are derived from responses from fewer than 50 contractors. Since the Roofing Contactors Association of California reports that there were approximately 5000 active roofing contractors statewide in 2002 (Hoffner 2002), the NRCA figures may lack statistical validity.

The 2001 Western Roofing and 2000 NRCA market estimates are presented in Table 2. Also shown are estimates of the western-region roof area coverage by product, based on Lawrence Berkeley National Laboratory (LBNL) estimates of typical roofing-product prices. BUR (27\%), modified bitumen (26\%), and single-ply membrane (22\%) cover $75 \%$ of the western-region roof area. While manufacturer reports of sales to the California market would have provided better estimates of the fraction of California roofs covered with each product, such data do not appear to be publicly available.

\footnotetext{
${ }^{5}$ The 14 western states included in this market are Alaska, Arizona, California, Colorado, Hawaii, Idaho, Montana, Nevada, New Mexico, Oregon, Texas, Utah, Washington, and Wyoming.
} 
There are over 200 companies manufacturing roofing products in the Unites States. Most manufacturers specialize by type of roofing material. However, firms that manufacture asphalt-based roofing products, such as asphalt shingles, built-up roofing, and/or modified bitumen, may offer all three. Companies that specialize in asphalt-based roofing have the largest sales volumes. Table 3 lists major roofing manufacturers and their primary products.

Roofing manufacturers sell most of their roofing products through distributors. The distributors generally contact the manufacturers to obtain materials, although some manufacturers also use

Table 3. Leading roofing product manufacturers (The Freedonia Group 1997; Builder 1995).

\begin{tabular}{|c|c|c|c|c|}
\hline Company & $\begin{array}{c}\text { Market } \\
\text { Share }\end{array}$ & Main Product & Product Mix & Sales \\
\hline Owens Corning & $8 \%$ & asphalt-based roofing & $\begin{array}{c}\text { multi-product } \\
\text { building materials }\end{array}$ & $\begin{array}{l}\text { local dealer/distributor and } \\
\text { factory-direct }\end{array}$ \\
\hline GAF Materials Corporation & $7 \%$ & asphalt-based roofing & $\begin{array}{c}\text { multi-product } \\
\text { building materials }\end{array}$ & no information \\
\hline $\begin{array}{c}\text { France-based Saint-Gobain } \\
\text { (via CertainTeed) }\end{array}$ & $6 \%$ & asphalt-based roofing & $\begin{array}{l}\text { multi-product } \\
\text { building materials }\end{array}$ & local dealer/distributor \\
\hline Jim Walter (via Celotex) & $3-4 \%$ & $\begin{array}{l}\text { asphalt-based roofing, } \\
\text { coatings }\end{array}$ & $\begin{array}{l}\text { multi-product } \\
\text { building materials }\end{array}$ & local dealer/distributor \\
\hline GS Roofing Products & $3-4 \%$ & asphalt-based roofing & specialty & local dealer/distributor \\
\hline Johns Manville & $3-4 \%$ & asphalt-based roofing & $\begin{array}{c}\text { multi-product } \\
\text { building materials }\end{array}$ & $\begin{array}{l}\text { local dealer/distributor } \\
\text { and factory-direct }\end{array}$ \\
\hline $\begin{array}{l}\text { Carlisle Companies } \\
\text { (via Carlisle SynTec) }\end{array}$ & $3-4 \%$ & elastomeric roofing & $\begin{array}{c}\text { multi-line rubber } \\
\text { products; metal roofing }\end{array}$ & no information \\
\hline $\begin{array}{l}\text { Japan-based Bridgestone } \\
\text { (via Firestone Building Products) }\end{array}$ & $3-4 \%$ & elastomeric roofing & $\begin{array}{l}\text { multi-line rubber } \\
\text { products; building } \\
\text { materials }\end{array}$ & no information \\
\hline Tamko Roofing Products & $<3 \%$ & asphalt-based roofing & specialty & local dealer/distributor \\
\hline $\begin{array}{l}\text { United Dominion Industries } \\
\text { (via AEP Span and Varco- } \\
\text { Pruden Buildings) }\end{array}$ & $<3 \%$ & metal roofing & $\begin{array}{l}\text { specialty pre- } \\
\text { engineered buildings }\end{array}$ & no information \\
\hline Gulf States Manufacturers & $<3 \%$ & metal roofing & $\begin{array}{l}\text { specialty pre- } \\
\text { engineered buildings }\end{array}$ & no information \\
\hline $\mathrm{NCl}$ Building Systems & $<3 \%$ & metal roofing & $\begin{array}{l}\text { specialty pre- } \\
\text { engineered buildings }\end{array}$ & no information \\
\hline $\begin{array}{l}\text { Australia-based Boral } \\
\text { (via US Tile and Lifetile) }\end{array}$ & $<3 \%$ & tile & no information & local dealer/distributor \\
\hline Clarke Group of Canada & $<3 \%$ & $\begin{array}{l}\text { cedar shingles and shakes; } \\
\text { fiber cement roofing }\end{array}$ & no information & no information \\
\hline Elcor (via Elk) & $<3 \%$ & asphalt shingles & no information & local dealer/distributor \\
\hline GenCorp & $<3 \%$ & $\begin{array}{l}\text { thermoplastic and rubber } \\
\text { membrane roofing }\end{array}$ & no information & no information \\
\hline Hood Companies & $<3 \%$ & $\begin{array}{l}\text { asphalt shingles and roll } \\
\text { roofing }\end{array}$ & no information & no information \\
\hline $\begin{array}{l}\text { Redland of the UK } \\
\text { (via Monier Roof Tile) }\end{array}$ & $<3 \%$ & tile & no information & local dealer/distributor \\
\hline Tremco & $<3 \%$ & $\begin{array}{c}\text { built-up and } \\
\text { membrane roofing }\end{array}$ & no information & no information \\
\hline
\end{tabular}


representatives to sell products.

Though more profitable for the manufacturer, factory-direct sales make up a smaller portion of the roofing market than does distribution, and are usually used only for large-quantity purchases. Manufacturers distribute most of their products through local outlets such as independent wholesale distributors and company-owned distribution centers.

From the distributor there are three main channels to the end-user: lumber yards ( 45 to $50 \%$ of sales), direct sales to large contractors or home builders (40\%), and retail establishments such as home improvement centers and hardware stores (10 to 15\%) (Freedonia Group 1997).

The EPA EnergyStar ${ }^{\circledR}$ roof program lists over 100 Roof Product Partners on its web site (http://yosemite1.epa.gov/estar/consumers.nsf/content/roofbus.htm). The EPA program allows manufacturers to self-certify their products' performance criteria and does not include a minimum emittance requirement for eligible roofing products. However, the web site lists over 250 non-metal roofing products that have an initial solar reflectance of 0.70 or higher.

\section{Cost Premiums}

Cool options are available for most types of low-sloped roofing. In estimating cost effectiveness for new construction and for regularly scheduled reroofing, we consider only the incremental initial cost of changing the reflectance of the roof from a low value to a high value. Table 4 lists estimates of typical incremental costs obtained from interviews of manufacturers, contractors, owners, and specifiers.

Additional expenditure would be required if a building owner wished to maintain the cool roof's

Table 4. Cost premiums for cool varieties of common low-sloped roofing products.

\begin{tabular}{|l|l|l|}
\hline Roofing Product & Cool Variety & Cost Premium $\left(\$ / \mathrm{ft}^{2}\right.$ ) \\
\hline ballasted BUR & use white gravel & up to 0.05 \\
BUR with smooth asphalt coating & use cementitious or other white coatings & 0.10 to 0.20 \\
BUR with aluminum coating & use cementitious or other white coatings & 0.10 to 0.20 \\
single-ply membrane (EPDM, TPO, CSPE, PVC) & use a white membrane & 0.00 to 0.05 \\
modified bitumen (SBS, APP) & use a white coating over the mineral surface & up to 0.05 \\
metal roofing (both painted and unpainted) & use a white or cool-color paint & 0.00 to 0.05 \\
roof coatings (dark color, asphalt base) & use a white or cool-color coating & 0.00 to 0.10 \\
concrete tile & use a white or cool-color tile & 0.00 to 0.05 \\
fiber-cement tile & use a white or cool-color tile & 0.05 \\
red clay tile & use a cool red tile & 0.10 \\
\hline
\end{tabular}


reflectance at its initial high level (i.e., $\rho \geq 0.70$ ). That additional cost has not been factored into the life-cycle cost (LCC) analysis because the simulated energy savings are based on a degraded reflectance $(0.55)$ that assumes no additional maintenance.

\section{Useful Life, Persistence and Maintenance}

Roof reflectance may change over time from aging, weathering, and soiling. Regular cleaning can mitigate the effects of soiling. A study monitoring the effects of aging and weathering on 10 California roofs found that the reflectance of cool materials can decrease by as much as 0.15 , mostly within the first year of service (Bretz and Akbari 1997). An ongoing study at LBNL has found similar reflectance degradations for an assortment of single-ply membrane roofs sited around the United States. Once the membranes were cleaned, their reflectances approached those of fresh roofing materials (Berhe et al. 2003).

Exposure tends to moderately decrease the reflectance of light-colored materials, while moderately increasing the reflectance of dark materials. LBNL's observations suggest that the aged solar reflectance of a roof may be estimated from the relation

$$
\rho_{\text {aged }}=\rho_{0}+c\left(\rho_{\text {initial }}-\rho_{0}\right)
$$

where constants $\rho_{0}=0.2$ and $c=0.7$. That is, the change to reflectance with aging is modeled as a $30 \%$ reduction in the difference between the initial reflectance and a value of 0.2 .6

ASHRAE Standard 90.1 (nonresidential buildings, section 5.3.1.1) assigns credits to cool roofs with a minimum reflectance of 0.70 (ASHRAE 2001). However, the credits are calculated based on an aged reflectance of 0.55, which is consistent with Eq. (1) (Akbari et al. 1998b). Like the ASHRAE calculations, the current Title 24 code assigns a degraded reflectance of 0.55 to a cool roof. The energy-savings analysis presented in this study will also use a degraded cool-roof solar reflectance of 0.55. The revised prescriptive-compliance and overall-envelope approaches use Eq. (1) to estimate degraded solar reflectance from initial solar reflectance.

\footnotetext{
${ }^{6}$ An equivalent expression relating aged solar absorptance to initial solar absorptance is $\alpha_{\text {aged }}=\alpha_{0}+c\left(\alpha_{\text {initial }}-\alpha_{0}\right)$, where constants $\alpha_{0}=0.8$ and $c=0.7$. This form is used in the performance approach because the Alternative Calculation Method (ACM) inputs initial absorptance, rather than initial reflectance.
} 
A cool roof has a lower daytime peak temperature than does a warm roof, reducing the thermal stress that results from diurnal temperature change. This is commonly believed to extend product life. However, potential product-lifetime increases have not been factored into cost-effectiveness calculations because long-term studies of this effect are not available.

\section{Environmental Impact}

Cool roofs are expected to have both positive and negative environmental impacts. Benefits include increased human comfort, slowed smog formation, and mitigation of urban heat islands in summer. Waste from disposal of roofs would also decrease if cool roofs last longer than warm roofs. Penalties include slightly higher wintertime heating energy use, degraded wintertime urban air quality, and, in some cases, use of water and detergents to clean roofs.

Cool roofs transfer less heat to the outdoor environment than do warm roofs. The resulting lower air temperatures can slow urban smog formation and increase human comfort both outdoors and in unconditioned buildings. On a clear summer afternoon, the air temperature in a typical North American urbanized area can be about 2 to $9^{\circ} \mathrm{F}\left(1\right.$ to $\left.5^{\circ} \mathrm{C}\right)$ hotter than that in the surrounding rural area. The additional air-conditioning use induced by this urban air temperature elevation is responsible for 5 to $10 \%$ of urban peak electric power demand, at a direct cost of several billion dollars annually. At the community scale, increasing the solar reflectance of roofs can effectively and inexpensively mitigate an urban heat island (Akbari et al. 2001).

Measured data and computer simulations studying the effect of temperature on Los Angeles smog show that lowering the ambient air temperature significantly reduces ozone concentration. The simulations predict a reduction in population-weighted smog (ozone) of 10 to $12 \%$ resulting from a 3 to $4{ }^{\circ} \mathrm{F}\left(1.5\right.$ to $\left.2{ }^{\circ} \mathrm{C}\right)$ cooling in ambient temperature. Cool roofs could contribute about one-third of this reduction. For some scenarios, a 10 to $12 \%$ reduction in ozone is comparable to that obtained by replacing all gasoline on-road motor vehicles with electric cars (Rosenfeld et al. 1995).

Electricity savings and peak-demand reduction yielded by cool roofs can reduce power-plant emissions of $\mathrm{NO}_{\mathrm{x}}, \mathrm{CO}_{2}$, and $\mathrm{PM} 10$, especially when peak demand reduction decreases the use of inefficient peak-power plants. 
Cool roofs may last longer than warm roofs because of reduced thermal stress. Thus, if installed in the course of either new construction or regularly scheduled roof replacement (i.e., once every 10 to 25 years), ${ }^{7}$ cool roofs would reduce waste and the need for landfill space.

Cool roofs tend to increase consumption of building heating energy. Of particular concern is the potential for cool roofs to increase gas-furnace emissions into local air districts where winter air pollution may be problematic. That is, if a building is cooled with remotely generated electric power, and heated with locally burned natural gas, installation of a cool roof may yield increased annual local emissions from natural gas combustion even while reducing annual energy consumption.

Small quantities of water and detergent may be used in cases where annual roof cleaning is required to maintain high reflectance. The use of potable water to clean roofs may be detrimental in California's frequent droughts, and the use of detergent may pollute ground water. One contractor interviewed cleans roofs without detergent, using high-pressure water (140 gal/1000 ft² [5.7 L/m²]) and baking soda $\left(0.5 \mathrm{lb} / 1000 \mathrm{ft}^{2}\left[2.4 \mathrm{~g} / \mathrm{m}^{2}\right]\right)$ to wash the roofs and neutralize acidic pollutants (Lease 2002).

\section{Performance Verification}

There are no additional performance verification or commissioning activities required to ensure proper installation and performance of cool roof products.

\section{Methodology for Title 24 Code Change}

\section{Existing Code}

Under the express terms adopted as emergency regulations on January 3, 2001, California's Title 24 code, "Building Energy Efficiency Standards for Residential and Non-Residential Buildings," defines a $\mathrm{cool}$ roof as a "roofing material with high solar reflectance and high emittance that reduces heat gain through the roof." Title 24 specifies rules for certification and labeling of roofing-product solar reflectance and thermal emittance. Cool roofs are not included in the prescriptive requirements for building envelopes, but roof reflectance is incorporated in the overall-envelope and performancebased approaches.

\footnotetext{
${ }^{7}$ Although Title 24 nonresidential energy standards apply only to roofs in new construction, the analysis presented in this study applies also to roof replacement. It would tend to underestimate savings in older buildings with less efficient cooling equipment.
} 
In the nonresidential-building overall-envelope approach, the roof's solar reflectance is factored into the building heat gain equation via specification of roof solar absorptance. (For an opaque surface like that of a roof, absorptance $=1$ - reflectance.) The solar absorptance of a proposed cool roof is set to 0.45 (solar reflectance 0.55 ), while that of a standard roof is fixed at 0.70 (solar reflectance $0.30)$.

The Residential and Nonresidential Alternative Calculation Method (ACM) Approval Manual for performance-based compliance also assigns reduced solar absorptance (increased solar reflectance) to cool roofs. The proposed cool roof absorptance is 0.45 (reflectance 0.55 ), while the standard roof absorptance is 0.70 (reflectance 0.30 ).

Section 118(f) of the Standards sets reflectance and emittance requirements for cool roofs. Clay and concrete tile roofs must have a minimum initial solar reflectance of 0.40 and a minimum thermal emittance of 0.75 to be considered cool, while all other cool roofing products are required to have a minimum initial solar reflectance of 0.70 and a minimum thermal emittance of 0.75 .

\section{Code Change Proposal}

The proposed change adds a prescriptive requirement for NR buildings with low-sloped roofs that establishes a thermal-emittance-dependent minimum initial solar roof reflectance 8 for each of California's 16 climate zones (Figure 1). A roof with an initial thermal emittance not less than 0.75 qualifies as cool if it has an initial solar reflectance not less than 0.70; a roof with an initial thermal emittance $\varepsilon_{\text {initial }}$ less than 0.75 (e.g., a metallic roof) qualifies as cool if it has an initial solar reflectance not less than $0.70+0.34 \times\left(0.75-\varepsilon_{\text {initial }}\right)$. The derivation of this thermal-emittancedependent minimum initial solar roof reflectance is presented in Appendix A (p. 41).

These prescribed reflectance values are based on an estimated life cycle cost (LCC) analysis for cool roofs. Since definite LCC savings were found in zones 2 through 16, and LCC savings were found in zone 1 under some circumstances, the same thermal-emittance-dependent minimum initial solar reflectance would be required for all climate zones. By establishing this prescriptive value, overallenvelope and performance approach calculations would result in compliance credits or penalties, depending on the product performance rating relative to the prescriptive requirement.

\footnotetext{
8 To stay cool, a surface with low thermal emittance requires a higher solar reflectance than does a surface with high thermal emittance. Hence, the minimum initial solar reflectance for cool roof is thermal-emittance dependent.
} 
No changes are made to prescriptive requirements for the solar reflectance and thermal emittance of roofs on NR buildings with other than low-sloped roofs, high-rise residential buildings, low-rise residential buildings, or guest rooms in hotel/motel buildings.

The prescriptive requirements for cool roofing products are revised to allow for low-emittance products that have exceptionally high solar reflectance. An existing provision qualifying moderatereflectance clay and concrete tiles as cool is restricted to low-rise residential applications and is not affected by this proposal.

The proposed change modifies all three envelope-compliance options, as described below. Revisions will be necessary to the Standards, Nonresidential Manual, Nonresidential ACM Manual, and compliance forms to reflect the changes. The Low-rise Residential Standards will remain unchanged.

Prescriptive Compliance. The proposed change would adopt requirements in each climate region for the thermal-emittance-dependent minimum initial solar reflectance of low-sloped roofs on nonresidential buildings. This would expand the list of prescriptive envelope requirements, since the 2001 revisions to Title 24 do not address cool roofs in the prescriptive compliance approach.

Performance Compliance. The 2001 revisions allow the inclusion of cool roofs as a compliance option for credit. The current proposal will use the newly established prescriptive requirements for low-sloped roofs on nonresidential buildings to determine the energy budget for performance compliance calculations, resulting in potential compliance credits or penalties. In addition, the ACM Manual will be modified to include an input for emittance for low-sloped roofs on NR buildings.

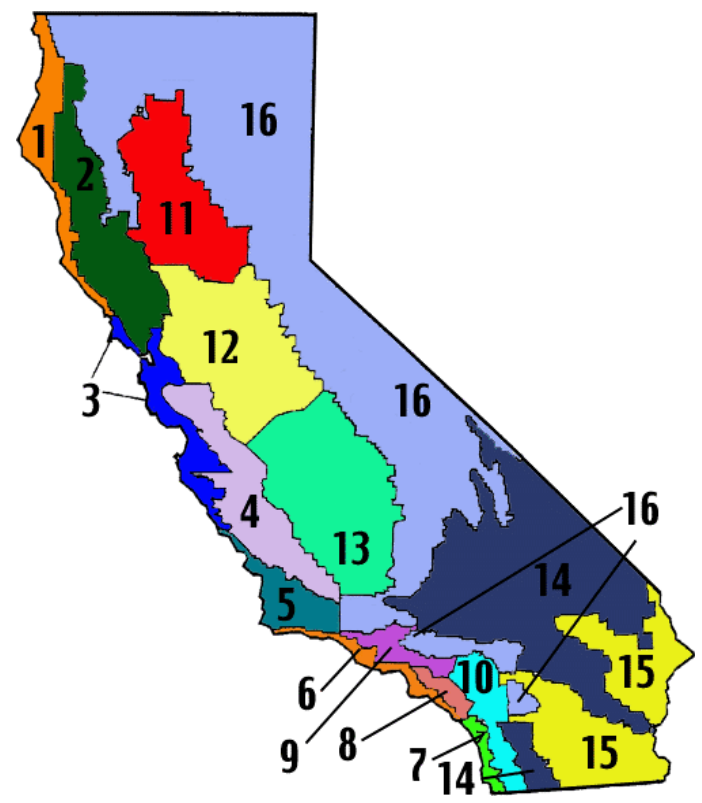

Figure 1. Locations of the 16 California climate zones. 
Overall-Envelope Approach. Since the overall-envelope approach does not factor in thermal emittance, this approach will apply only to roofs with thermal emittance not less than 0.75 (typically non-metallic), and may not be used for metallic roof surfaces (e.g., bare metal, galvanized steel, or aluminum coating). For low-sloped roofs on nonresidential buildings, the Standard Heat Gain Equation will reference the applicable initial solar reflectance from the Prescriptive Envelope Criteria table (Table 1-H in the 2001 Standards), and then degrade it to determine the aged value for the standard building roof solar reflectance. Currently, the equations use a constant value of 0.45 for solar absorptance (solar reflectance 0.55) and do not address thermal emittance. The Proposed Heat Gain Equation will degrade the Cool Roof Rating Council (CRRC) ${ }^{9}$ certified values for initial solar reflectance to determine the value for the proposed building's aged solar roof reflectance. Products not rated by CRRC will be assigned a default initial solar reflectance of 0.10 .

\section{Relationship to Other Measures}

Cool roofs can reduce needs for roof insulation, ceiling insulation, cooling capacity, air-handling-unit capacity, and plenum ventilation capacity.

- The effect of a cool roof is inversely proportional to the level of insulation. With the current prescriptive requirements, total building energy use is reduced by cool roof installation, and this installation is cost effective (Akbari et al. 1998b).

- A cool roof could reduce building cooling load by $0.1-0.5 \mathrm{~W} / \mathrm{ft}^{2}$ [1 - $5 \mathrm{~W} / \mathrm{m}^{2}$ ], depending on building type, roof insulation, and climate zone. Hence, the cooling unit can potentially be downsized.

- A building's air-handling unit (AHU) is typically designed to accommodate the summer peak cooling load. A lower summer peak cooling load can reduce the size of the AHU and save electricity. The smaller AHU can also operate more efficiently and use less electricity during the heating season.

- Cool roofs reduce the need for plenum ventilation. In many cases, a cool roof can eliminate the need for mechanical attic ventilation.

\footnotetext{
9 The Cool Roof Rating Council (http://coolroofs.org) is an independent organization established to provide cool-roof radiative property data.
} 


\section{Cost Effectiveness Analysis of Code Change}

Cool-roof cost effectiveness can be estimated by quantifying five parameters: annual decrease in cooling electricity consumption, annual increase in heating electricity and/or gas consumption, net present value (NPV) of net energy savings, cost savings from downsizing cooling equipment, and the cost premium for a cool roof. Cost premiums were based on interviews of manufacturers, contractors, owners, and specifiers, while savings were estimated via computer simulation of building energy use. Four other parameters can yield cool-roof benefits, but were not included in this determination of cost-effectiveness: peak cooling electricity demand reduction (specifically, cost savings and air-quality improvements associated with reduced use of peak-power generation); expenditure decrease from participation in a load curtailment program; expenditure decrease from participation in a reflective-roof rebate program; and savings in material and labor costs from the extended lives of the roof's surface and insulation.

LBNL's DOE-2.1E building energy simulation model (BESG 1990; Winkelmann et al. 1993) was used to estimate for each of California's 16 climate zones the effects of a cool roof on the uses of cooling and heating energy by a prototypical Title 24-compliant building. Simulated savings were shown to be comparable to savings measured for several buildings retrofitted with cool roofs. Finally, the simulated estimates of savings per $1000 \mathrm{ft}^{2}$ [and per $\mathrm{m}^{2}$ ] of cool roof area were combined with a profile of California's nonresidential new construction (NRNC) and California Energy Commission (hereafter, simply Commission) projections of annual NRNC area additions to predict statewide savings.

\section{Methodology}

\section{Simulated Building Energy Savings}

The latest version of DOE-2.1E is release 114, which adds minor improvements in energy calculation algorithms and can model more complex buildings and systems. DOE-2.1E has multiple merits: it is based on known and published existing algorithms; it has over 20 years of experience and feedback from the simulation community; it can handle many complex heating and cooling zones and systems; and it has been validated for many test cases, lending confidence to its use. The major disadvantage of DOE-2.1E is that many of its basic algorithms are 20 to 30 years old, and have been surpassed by more accurate modern algorithms. In particular, the radiation exchange algorithms in DOE-2.1E couple the surface temperature to that of the zone air, which makes its estimation of the effect of cool roofs on building energy use too low, particularly for buildings with a plenum space. In a study of 
school buildings in Sacramento, DOE-2.1E simulations of energy and peak power savings were 37\% and $57 \%$ below measured values (Akbari et al. 1993). We employed DOE-2.1E in the current study because this model is widely used for analyses of Title 24 requirements, and because we expect its predictions of energy savings to be conservative.

We constructed a prototypical Title 24 single-story, $4900 \mathrm{ft}^{2}$ [455 $\mathrm{m}^{2}$ ] small office building with five cooling/heating zones-one interior zone, and four equal-area perimeter zones (Table 5). Title 24 building characteristics (envelope, air-conditioner energy efficiency ratio [EER], interior load and schedules) were obtained from the Commission's 2001 Energy Efficiency Standards Report (CEC 2001). Each zone is served by an EER10 packaged rooftop air conditioner and a natural-gas furnace. A constant-volume air handler supplies air to each zone through ducts and returns the air through a plenum above a dropped ceiling. The building was assigned the level of roof insulation prescribed by Title 24, which is R-11 [1.9 $\mathrm{m}^{2} \mathrm{~K} / \mathrm{W}$ ] in the southern coastal areas (zones 6 through 9: Los Angeles Beach, San Diego, Santa Ana, and Los Angeles City) and R-19 [3.4 m² K/W] elsewhere. Wall insulation was R-13 [2.3 $\mathrm{m}^{2} \mathrm{~K} / \mathrm{W}$ ], which meets or exceeds Title 24 requirements of R-11 to R-13 [1.9 to $\left.2.3 \mathrm{~m}^{2} \mathrm{~K} / \mathrm{W}\right]$.

The DOE-2.1E simulations estimated annual cooling and ventilation electricity use $\left(\mathrm{kWh} / 1000 \mathrm{ft}^{2}\right.$ $\left[\mathrm{kWh} / \mathrm{m}^{2}\right]$ ), annual heating natural gas use (therms/1000 $\mathrm{ft}^{2}\left[\mathrm{MJ} / \mathrm{m}^{2}\right]$ ), and peak cooling and ventilation power demand $\left(\mathrm{kW} / 1000 \mathrm{ft}^{2}\left[\mathrm{~W} / \mathrm{m}^{2}\right]\right)$. Cool-roof-induced annual energy and peak power savings were determined by simulating the building twice: once with a cool roof (aged $\rho=0.55$, $\varepsilon=0.90$ ), and once with a noncool roof (aged $\rho=0.20, \varepsilon=0.90$ ). This corresponds to a reflectance difference of $\Delta \rho_{0}=0.35$ with unchanged emittance. Since savings are linearly proportional to the change in roof reflectance (Konopacki et al. 1997), savings for some other reflectance difference $\Delta \rho_{1}$ can be calculated from

$$
\text { savings }_{\Delta \rho_{1}}=\left(\Delta \rho_{1} / \Delta \rho_{0}\right) \times \text { savings }_{\Delta \rho_{0}} \text {. }
$$

Annual source energy savings (source MBTU/1000 ft² [source $\left.\mathrm{MJ} / \mathrm{m}^{2}\right]$ ) were calculated from annual electricity and natural gas savings using conversion factors of 10.239 source kBTU/kWh [10.8 source $\mathrm{MJ} / \mathrm{kWh}$ ] (33\% combined generation and distribution efficiency) and 100 source kBTU/therm [1 source MJ/MJ] (100\% distribution efficiency). 
Table 5. Characteristics of the prototypical Title 24 single-story small office building used in DOE2.1E simulations of cool-roof energy savings (CEC 2001).

\begin{tabular}{|c|c|c|}
\hline general & $\begin{array}{c}\text { floor/roof area } \\
\text { orientation } \\
\text { north/south } \\
\text { east/west } \\
\text { conditioned zones }\end{array}$ & $\begin{array}{c}4900 \mathrm{ft}^{2} \\
\text { non-directional } \\
70^{\prime} \\
70^{\prime} \\
5 \\
\end{array}$ \\
\hline zones & $\begin{array}{l}\text { perimeter-north } \\
\text { perimeter-south } \\
\text { perimeter-east } \\
\text { perimeter-west } \\
\text { interior }\end{array}$ & $\begin{array}{c}825 \mathrm{ft}^{2} \\
825 \mathrm{ft}^{2} \\
825 \mathrm{ft}^{2} \\
825 \mathrm{ft}^{2} \\
1600 \mathrm{ft}^{2}\end{array}$ \\
\hline roof construction & $\begin{array}{c}\text { built-up with grey mineral capsheet } \\
\text { built-up with white coated mineral capsheet } \\
3 / 4 " \text { plywood deck } \\
\text { return air plenum (unconditioned) } \\
\text { insulation } \\
\text { dropped t-bar ceiling with } 1 / 2 \text { " acoustical tile }\end{array}$ & $\begin{array}{l}\text { base case } \\
\text { cool case } \\
\text { low-slope } \\
\text { R-11 or R-19 }\end{array}$ \\
\hline roof solar reflectance & $\begin{array}{c}\text { base case } \\
\text { aged cool case }\end{array}$ & $\begin{array}{l}0.20 \\
0.55\end{array}$ \\
\hline roof thermal emittance & $\begin{array}{c}\text { base case } \\
\text { aged cool case }\end{array}$ & $\begin{array}{l}0.90 \\
0.90\end{array}$ \\
\hline wall construction & $\begin{array}{c}\text { brick } \\
\text { wood frame }(15 \%) \\
\text { insulation }(85 \%) \\
1 / 2 " \text { drywall } \\
\text { height }\end{array}$ & $\begin{array}{l}\mathrm{R}-13 \\
9^{\prime}\end{array}$ \\
\hline windows & $\begin{array}{c}\text { window-to-wall ratio } \\
\text { double-pane } \\
\text { operable shades }\end{array}$ & $\begin{array}{l}0.50 \\
\text { clear } \\
\text { yes }\end{array}$ \\
\hline foundation & $\begin{array}{l}\text { concrete slab-on-grade } \\
\text { carpet with pad }\end{array}$ & \\
\hline cooling equipment & $\begin{array}{c}\text { packaged rooftop air conditioner } \\
\text { capacity } \\
\text { EER } \\
\text { COP } \\
\text { set-point }\end{array}$ & $\begin{array}{c}5 \text { (1 unit per zone) } \\
\text { auto-sized } \\
10 \\
2.9 \\
78^{\circ} \mathrm{F}\end{array}$ \\
\hline heating equipment & $\begin{array}{c}\text { natural gas furnace } \\
\text { capacity } \\
\text { efficiency } \\
\text { set-point }\end{array}$ & $\begin{array}{c}5 \text { (1 unit per zone) } \\
\text { auto-sized } \\
74 \% \\
70 \% \\
\end{array}$ \\
\hline distribution & $\begin{array}{c}\text { constant-volume forced air system } \\
\text { capacity } \\
\text { fan efficiency } \\
\text { economizer } \\
\text { duct leakage } \\
\text { duct temperature drop } \\
\text { outside air }\end{array}$ & $\begin{array}{c}5 \text { (1 unit per zone) } \\
\text { auto-sized } \\
0.54 \text { W/cfm } \\
\text { temperature } \\
10 \% \\
1{ }^{\circ} \mathrm{F} \\
15 \mathrm{cfm} / \text { person }\end{array}$ \\
\hline operation & $\begin{array}{c}\text { weekdays } \\
\text { Saturday }\end{array}$ & $\begin{array}{l}\text { 9am to } 6 \mathrm{pm} \\
\text { 9am to noon }\end{array}$ \\
\hline interior loads & $\begin{array}{l}\text { infiltration (Title } 24 \text { schedule W-23) } \\
\text { lighting (Title } 24 \text { schedule W-25) } \\
\text { equipment (Title } 24 \text { schedule W-24) } \\
\text { occupants (Title } 24 \text { schedule W-26) }\end{array}$ & $\begin{array}{l}0.5 \mathrm{ACH} \\
1.2 \mathrm{~W} / \mathrm{ft}^{2} \\
1.5 \mathrm{~W} / \mathrm{ft}^{2} \\
25\end{array}$ \\
\hline
\end{tabular}


Table 6. Life expectancies of roofing materials (NRCA 1998; Lufkin and Pepitone 1997).

\begin{tabular}{|c|c|}
\hline Roofing Material & Life Expectancy (years) \\
\hline wood shingles and shakes & 15 to 30 \\
tile $^{a}$ & 50 \\
sheet metal $^{b}$ & 20 to $50+$ \\
BUR/asphaltc & 12 to 25 \\
BUR/coat and tarc & 12 to 30 \\
single-ply modified bitumen & 10 to 20 \\
single-ply thermoplastic & 10 to 20 \\
single-ply thermoset & 10 to 20 \\
asphalt shingle & 15 to 30 \\
asphalt overlay & 25 to 35 \\
\hline
\end{tabular}

a. Depends on quality of tile, thoroughness of design, and climate.

$b$. Depends on gauge of metal, quality of coating, thoroughness of design and application.

c. Depends on materials and drainage; coatings will add to life span.

The 15-year net present value (NPV) of savings (\$/1000 ft2 $\left[\$ / \mathrm{m}^{2}\right]$ ) was calculated with and without time dependent valuation (TDV). A period of 15 years was chosen to be consistent with the typical lifetime of a low-sloped nonresidential building roof (Table 6).

The TDV method assigns 15-year unit values of NPV to electricity $(\$ / \mathrm{kWh})$ and natural gas $(\$ /$ therm or $\$ / \mathrm{MJ}$ ) that vary with hour of year and climate zone. These hourly multipliers are used to calculate the NPVs of savings achieved in each of the 8760 hours in a year. Summing these hourly savings yields the TDV NPV (\$).

The non-TDV method converts annual electricity savings and annual natural gas savings to NPV \$ using NPV multipliers (\$1.37/kWh and $\$ 7.30 /$ therm $[\$ 0.069 / \mathrm{MJ}]$ ) based on 15-year projections of statewide annual average electricity and gas prices. The same multipliers are used in every climate zone (Eley Associates 2002).

It should be noted that the energy conversion factors and NPV multipliers were specified by the California Energy Commission, and might not be representative of efficiencies and prices outside California.

The average cost per $\mathrm{kW}$ of cooling capacity ranges from $\$ 560$ to $\$ 660$ for a package system, from $\$ 560$ to $\$ 670$ for a split system, and from $\$ 350$ to $\$ 480$ for a central (i.e., multi-zone, built-up) system, exclusive of the air handling unit (Somasundaram et al. 2000). Since the air handling unit typically costs about half as much as the rest of a central cooling system, the total cost for a central system ranges from about 525 to $720 \$ / \mathrm{kW}$. Thus, initial cost savings available from downsizing the 
air conditioning system were conservatively estimated at $\$ 500 / \mathrm{kW}$. Equipment cost savings were added to energy savings to determine total savings.

\section{Projected Statewide Energy Savings for Nonresidential New Construction}

A database of NRNC (RLW 1999) describes 990 sample California nonresidential buildings, providing each building's floor area, roof area, climate zone, building type, and "case weight" factor indicating how representative the sample building is of California NRNC. We denote the total caseweighted roof area of daytime-conditioned ${ }^{10}$ sample buildings in climate zone $i$ as $R_{\text {samples }, i}$, and the total case-weighted floor area of all 990 sample buildings as $F_{\text {samples }}$.

If the rate of savings per unit roof area in climate zone $i$ is $S_{i}$, statewide savings per unit floor area can be estimated as $\sum_{i} S_{i} \times\left(R_{\text {samples }, i} / F_{\text {samples }}\right)$.

Over the period 2001-2010, the Commission predicts annual additions to NR floor area ranging from 154 to $164 \mathrm{Mft}^{2}$ [14.3 to $15.2 \mathrm{~km}^{2}$ ], averaging $158 \mathrm{Mft}^{2}$ [14.7 km²] (CEC 2000). We assume as a qualified guess that $80 \%$ of the NRNC would be low-sloped (i.e., have a low-sloped roof), and that $80 \%$ of the low-sloped NRNC would be built with a noncool roof. Hence, the total floor area of coolroofable, low-sloped, daytime-conditioned NRNC is $80 \% \times 80 \%=64 \%$ of $158 \mathrm{Mft}^{2}$ [ $14.7 \mathrm{~km}^{2}$ ], or $101 \mathrm{Mft}^{2}$ [9.4 km²]. This is the state NRNC floor area to which cool-roof savings are applicable, denoted $F_{\text {CA,applicable }}$.

Statewide savings can be estimated from the expression $F_{\mathrm{CA} \text {,applicable }} \times \sum_{i} S_{i} \times\left(R_{\text {samples }, i} / F_{\text {samples }}\right)$.

\section{Measured Building Energy Savings}

Prior studies have measured daily air-conditioning energy savings and peak power demand reduction from the use of cool roofs on nonresidential buildings in several warm-weather climates, including California, Florida, and Texas. Daily energy savings measured after increasing roof reflectance were annualized by multiplying daily savings (kWh/day) by the number of cooling days per year. Energy

\footnotetext{
10 The NRNC database defines 17 building types. The 10 types that are expected to be conditioned during the day-grocery store, medical/clinical, office, restaurant, retail and wholesale store, school, theater, hotels/motel, community center, and library-are denoted "daytime-conditioned." Seven other typescommercial and industrial (C\&l) storage (warehouse), general C\&l work (factory), other, religious worship/auditorium/convention, unknown, fire/police/jail, and gymnasium-may be conditioned during the day, but are excluded from the estimated statewide cool-roof area because significant fractions of their cooling loads may be incurred during the evening.
} 
and peak-demand savings were also lowered to account for reflectance reduction resulting from roof weathering. Degraded annual energy savings (kWh) and peak demand reduction (kW) were normalized per $1000 \mathrm{ft}^{2}\left[\mathrm{~m}^{2}\right]$ of roof area for comparison with simulated results $\left(\mathrm{kWh} / 1000 \mathrm{ft}^{2}\right.$ and $\mathrm{kW} / 1000 \mathrm{ft}^{2}\left[\mathrm{kWh} / \mathrm{m}^{2}\right.$ and $\left.\left.\mathrm{W} / \mathrm{m}^{2}\right]\right)$. This study uses the measured data as practical evidence that cool roofs provide energy and peak power savings, but it relies solely on DOE-2.1E simulation results for the cost-effectiveness analysis.

\section{Results}

\section{Simulated Building Energy Savings for New Construction}

Simulated cool-roof savings by climate zone are detailed in Table 7.

Annual electricity savings ranged from 115 to $413 \mathrm{kWh} / 1000 \mathrm{ft}^{2}$ (average $297 \mathrm{kWh} / 1000 \mathrm{ft}^{2}$ ) [1.24 to $4.45 \mathrm{kWh} / \mathrm{m}^{2}$ (average $3.20 \mathrm{kWh} / \mathrm{m}^{2}$ )] (Figure 2).

Annual natural gas deficits ranged from 1.7 to 10.6 therm/1000 ft² (average 4.9 therm/1000 $\mathrm{ft}^{2}$ ) [1.9 to $12.0 \mathrm{MJ} / \mathrm{m}^{2}$ (average $5.6 \mathrm{MJ} / \mathrm{m}^{2}$ )] (Figure 3).

Table 7. Simulated Title 24 cool-roof annual energy, peak demand, cooling equipment cost, and net present value (NPV) dollar savings (energy only, and total = energy + equipment) for a prototypical Title 24 building in each California climate zone, with and without time dependent valuation (TDV). Savings are computed for each zone's prescribed level of roof insulation, and normalized per $1000 \mathrm{ft}^{2}$ of air-conditioned roof area.

\begin{tabular}{|c|c|c|c|c|c|c|c|c|c|c|c|c|c|c|}
\hline \multirow{2}{*}{$\begin{array}{l}\text { climate } \\
\text { zone }\end{array}$} & \multirow[b]{2}{*}{$\begin{array}{c}\text { roof } \\
R \text {-value }\end{array}$} & \multicolumn{3}{|c|}{$\begin{array}{c}\text { annual energyl } \\
1000 \mathrm{ft}^{2}\end{array}$} & \multicolumn{2}{|c|}{$\begin{array}{c}\text { peak powerl } \\
1000 \mathrm{ft}^{2}\end{array}$} & \multicolumn{4}{|c|}{$\begin{array}{l}\text { TDV NPVI } \\
1000 \mathrm{ft}^{2}\end{array}$} & \multicolumn{4}{|c|}{$\begin{array}{c}\text { non-TDV NPVI } \\
1000 \mathrm{ft}^{2}\end{array}$} \\
\hline & & kWh & therm & $\begin{array}{l}\text { source } \\
\text { MBTU }\end{array}$ & kW & \$equip & $\$ k W h$ & \$therm & \$energy & \$total & \$kWh & \$therm & \$energy & \$total \\
\hline 1 & 19 & 115 & -8.3 & 0.3 & 0.13 & 67 & 183 & -74 & 109 & 176 & 157 & -62 & 95 & 162 \\
\hline 2 & 19 & 295 & -5.9 & 2.4 & 0.20 & 100 & 494 & -51 & 442 & 542 & 405 & -43 & 362 & 462 \\
\hline 3 & 19 & 184 & -4.9 & 1.4 & 0.15 & 76 & 335 & -42 & 294 & 370 & 253 & -35 & 218 & 294 \\
\hline 4 & 19 & 246 & -4.2 & 2.1 & 0.18 & 90 & 417 & -37 & 380 & 470 & 337 & -31 & 306 & 396 \\
\hline 5 & 19 & 193 & -4.7 & 1.5 & 0.17 & 83 & 342 & -42 & 300 & 383 & 265 & -35 & 230 & 313 \\
\hline 6 & 11 & 388 & -4.1 & 3.6 & 0.22 & 111 & 632 & -36 & 596 & 707 & 532 & -29 & 503 & 614 \\
\hline 7 & 11 & 313 & -2.6 & 2.9 & 0.25 & 125 & 514 & -24 & 489 & 614 & 428 & -20 & 408 & 533 \\
\hline 8 & 11 & 413 & -3.7 & 3.9 & 0.25 & 125 & 681 & -34 & 647 & 772 & 565 & -28 & 537 & 662 \\
\hline 9 & 11 & 402 & -4.5 & 3.7 & 0.20 & 101 & 657 & -39 & 618 & 719 & 552 & -33 & 519 & 620 \\
\hline 10 & 19 & 340 & -3.6 & 3.1 & 0.18 & 89 & 553 & -31 & 521 & 610 & 467 & -26 & 441 & 530 \\
\hline 11 & 19 & 268 & -4.9 & 2.3 & 0.15 & 75 & 455 & -44 & 411 & 486 & 368 & -37 & 331 & 406 \\
\hline 12 & 19 & 286 & -5.3 & 2.4 & 0.19 & 95 & 486 & -47 & 438 & 533 & 392 & -39 & 353 & 448 \\
\hline 13 & 19 & 351 & -5.1 & 3.1 & 0.19 & 96 & 592 & -44 & 547 & 643 & 480 & -37 & 443 & 539 \\
\hline 14 & 19 & 352 & -4.7 & 3.1 & 0.21 & 105 & 576 & -40 & 536 & 641 & 483 & -33 & 450 & 555 \\
\hline 15 & 19 & 380 & -1.7 & 3.7 & 0.16 & 82 & 599 & -16 & 583 & 665 & 520 & -13 & 507 & 589 \\
\hline 16 & 19 & 233 & -10.6 & 1.3 & 0.18 & 90 & 401 & -92 & 309 & 399 & 319 & -78 & 242 & 332 \\
\hline \multicolumn{2}{|c|}{$\min$} & 115 & -10.6 & 0.3 & 0.13 & 67 & 183 & -92 & 109 & 176 & 157 & -78 & 95 & 162 \\
\hline \multicolumn{2}{|c|}{$\max$} & 413 & -1.7 & 3.9 & 0.25 & 125 & 681 & -16 & 647 & 772 & 565 & -13 & 537 & 662 \\
\hline \multicolumn{2}{|c|}{ avg } & 297 & -4.9 & 2.6 & 0.19 & 94 & 495 & -43 & 451 & 545 & 408 & -36 & 372 & 466 \\
\hline
\end{tabular}


Annual source energy savings ranged from 0.3 to $3.9 \mathrm{MBTU} / 1000 \mathrm{ft}^{2}$ (average $2.6 \mathrm{MBTU} / 1000 \mathrm{ft}^{2}$ ) [3.4 to $44.3 \mathrm{MJ} / \mathrm{m}^{2}$ (average $29.5 \mathrm{MJ} / \mathrm{m}^{2}$ )] (Figure 4).

Peak power demand savings ranged from 0.13 to $0.25 \mathrm{~kW} / 1000 \mathrm{ft}^{2}$ (average $0.19 \mathrm{~kW} / 1000 \mathrm{ft}^{2}$ ) [1.4 to $2.7 \mathrm{~W} / \mathrm{m}^{2}$ (average $2.1 \mathrm{~W} / \mathrm{m}^{2}$ )] (Figure 5). This yielded cooling equipment cost savings of 67 to $125 \$ / 1000 \mathrm{ft}^{2}$ (average $\$ 94 / 1000 \mathrm{ft}^{2}$ ) [0.72 to $1.35 \$ / \mathrm{m}^{2}$ (average $\$ 1.01 / \mathrm{m}^{2}$ )]

Fifteen-year net present value energy savings ranged from 109 to $647 \$ / 1000 \mathrm{ft}^{2}$ (average $\$ 451 / 1000 \mathrm{ft}^{2}$ ) [1.17 to $6.96 \$ / \mathrm{m}^{2}$ (average $\$ 4.85 / \mathrm{m}^{2}$ )] with TDV, and from 95 to $537 \$ / 1000 \mathrm{ft}^{2}$ (average $\$ 372 / 1000 \mathrm{ft}^{2}$ ) [1.02 to $5.78 \$ / \mathrm{m}^{2}$ (average $\$ 4.00 / \mathrm{m}^{2}$ )] without TDV (Figure 6).

Total savings (cooling-equipment cost savings + 15-year NPV energy savings) ranged from 176 to $772 \$ / 1000 \mathrm{ft}^{2}$ (average $\$ 545 / 1000 \mathrm{ft}^{2}$ ) [1.89 to $8.31 \$ / \mathrm{m}^{2}$ (average $\$ 5.87 / \mathrm{m}^{2}$ )] with TDV, and from 162 to $662 \$ / 1000$ (average $\$ 466 / 1000 \mathrm{ft}^{2}$ ) [1.74 to $7.13 \$ / \mathrm{m}^{2}$ (average $\$ 5.02 / \mathrm{m}^{2}$ )] without TDV (Figure 7). The value of equipment savings was about 19\% that of TDV NPV energy savings, and about $23 \%$ that of non-TDV NPV energy savings.

The greatest annual electricity savings (kWh) were found in the southern inland areas (climate zones 13, 14, and 15), which are hot; and on the southern coast (zones 6, 8, and 9), where the prescribed roof insulation level is only R-11 [1.9 $\left.\mathrm{m}^{2} \mathrm{~K} / \mathrm{W}\right]$. The smallest savings were found along the north coast (zone 1), along the central coast (zones 3 and 5), and in the mountains (zone 16).

Since the NPV (both TDV and non-TDV) of the annual natural gas deficit was typically small compared to that of the annual electricity savings, the NPV of energy savings was also greatest in the southern inland and southern coastal climate zones. 


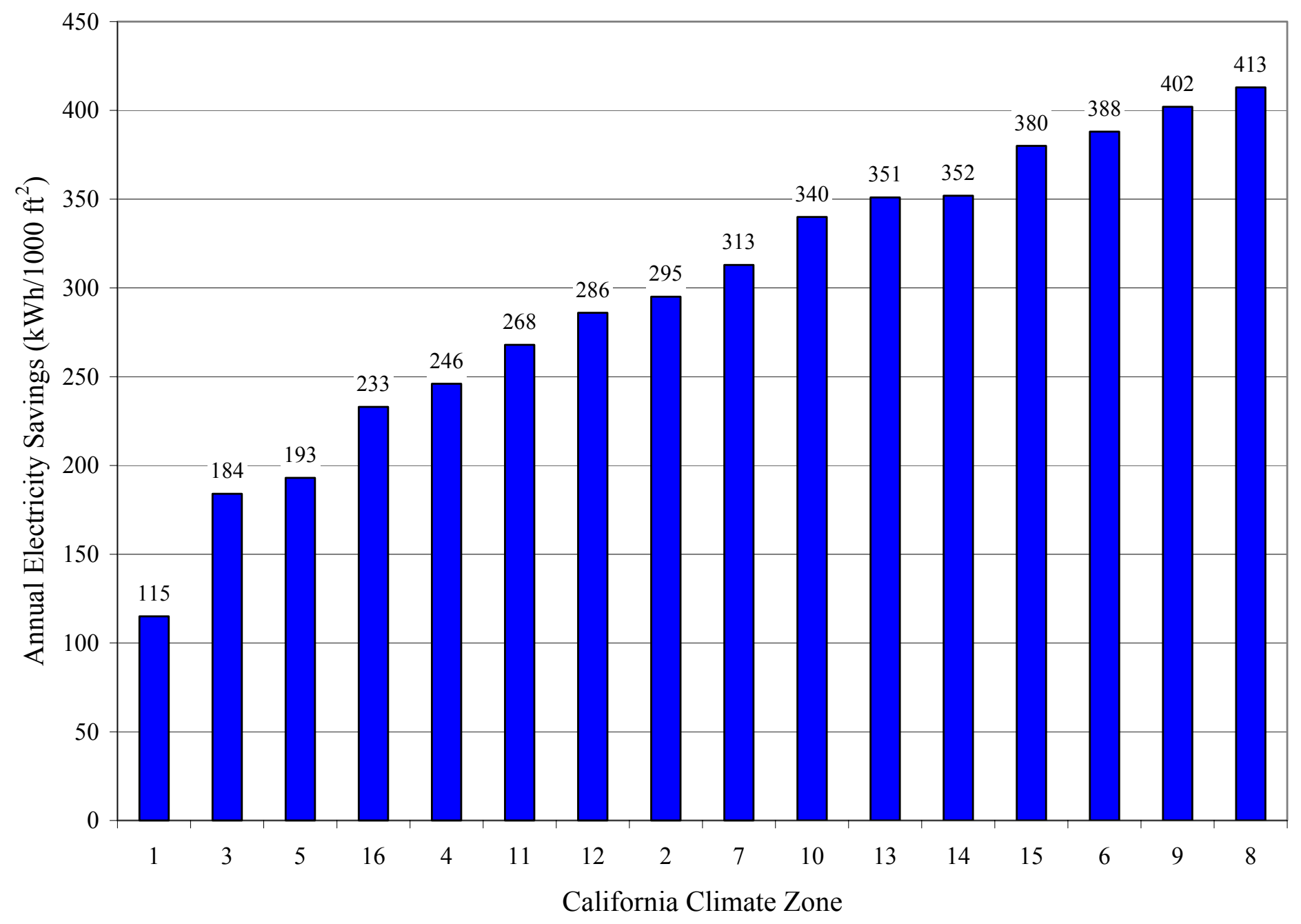

Figure 2. Annual electricity savings $\left(\mathrm{kWh} / 1000 \mathrm{ft}^{2}\right)$ by California climate zone, simulated for a prototypical Title 24 building with a cool roof. 


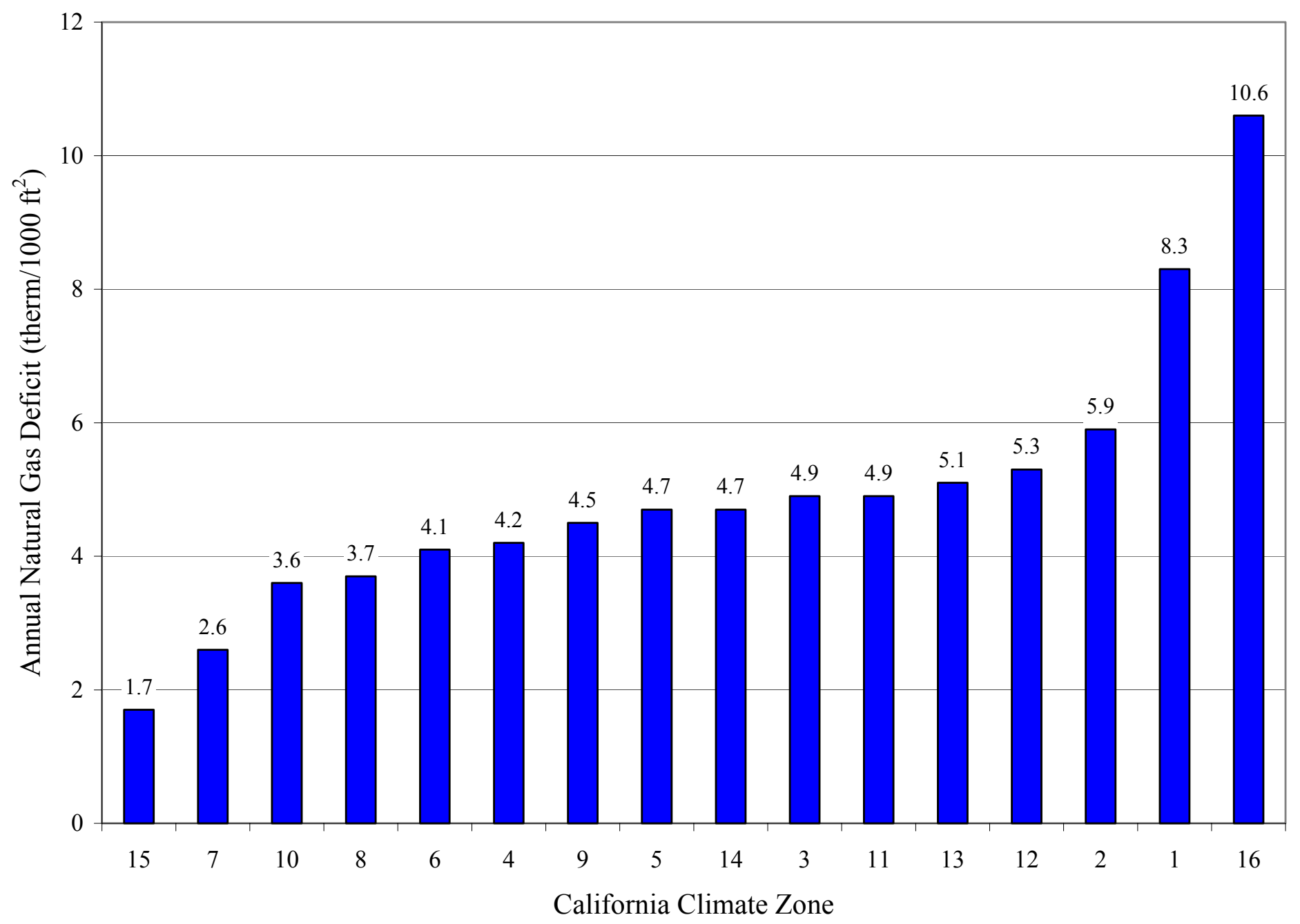

Figure 3. Annual natural gas deficit (therms/1000 ft²) by California climate zone, simulated for a prototypical Title 24 building with a cool roof. 


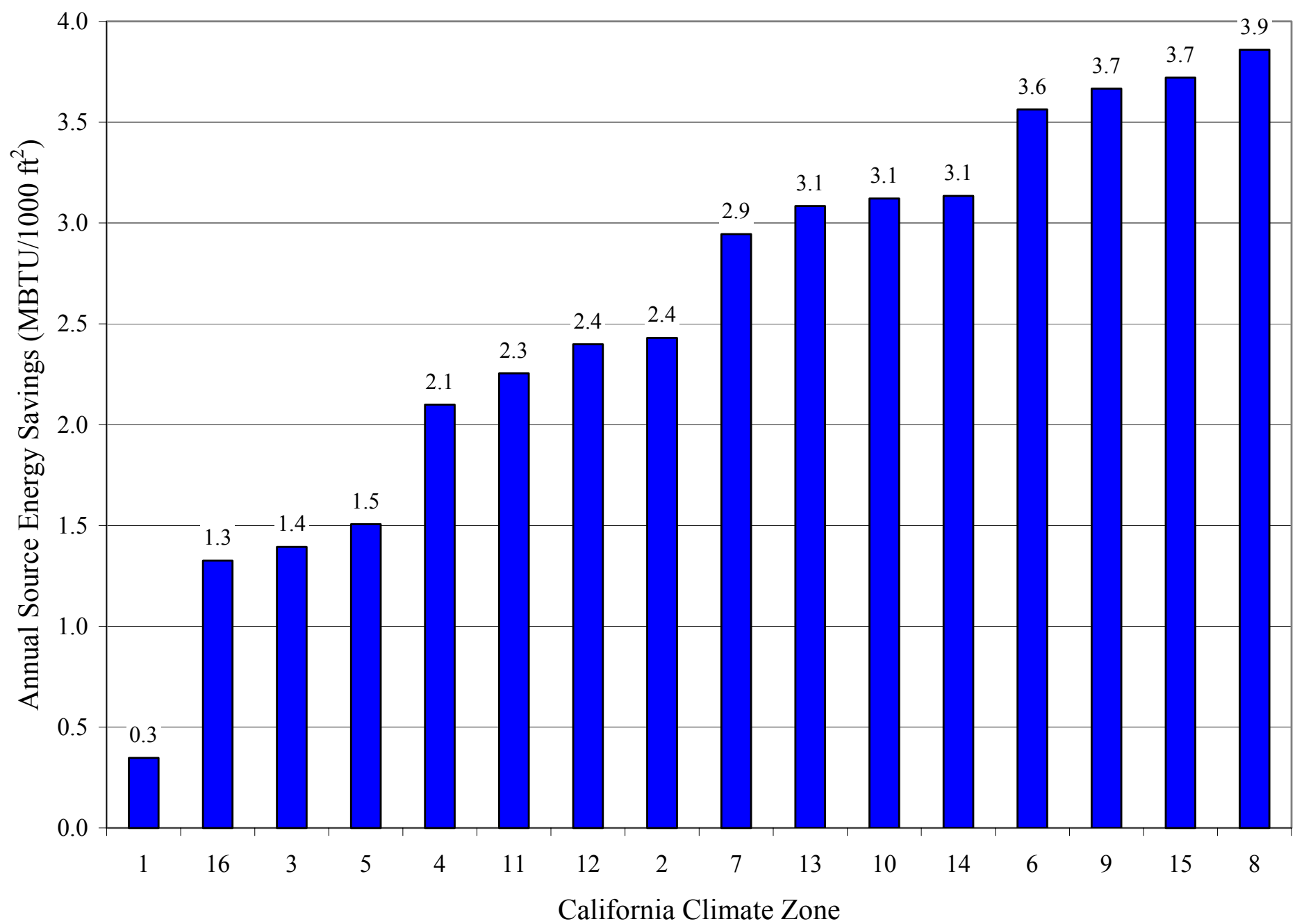

Figure 4. Annual source energy savings (MBTU/1000 ft2) by California climate zone, simulated for a prototypical Title 24 building with a cool roof. 


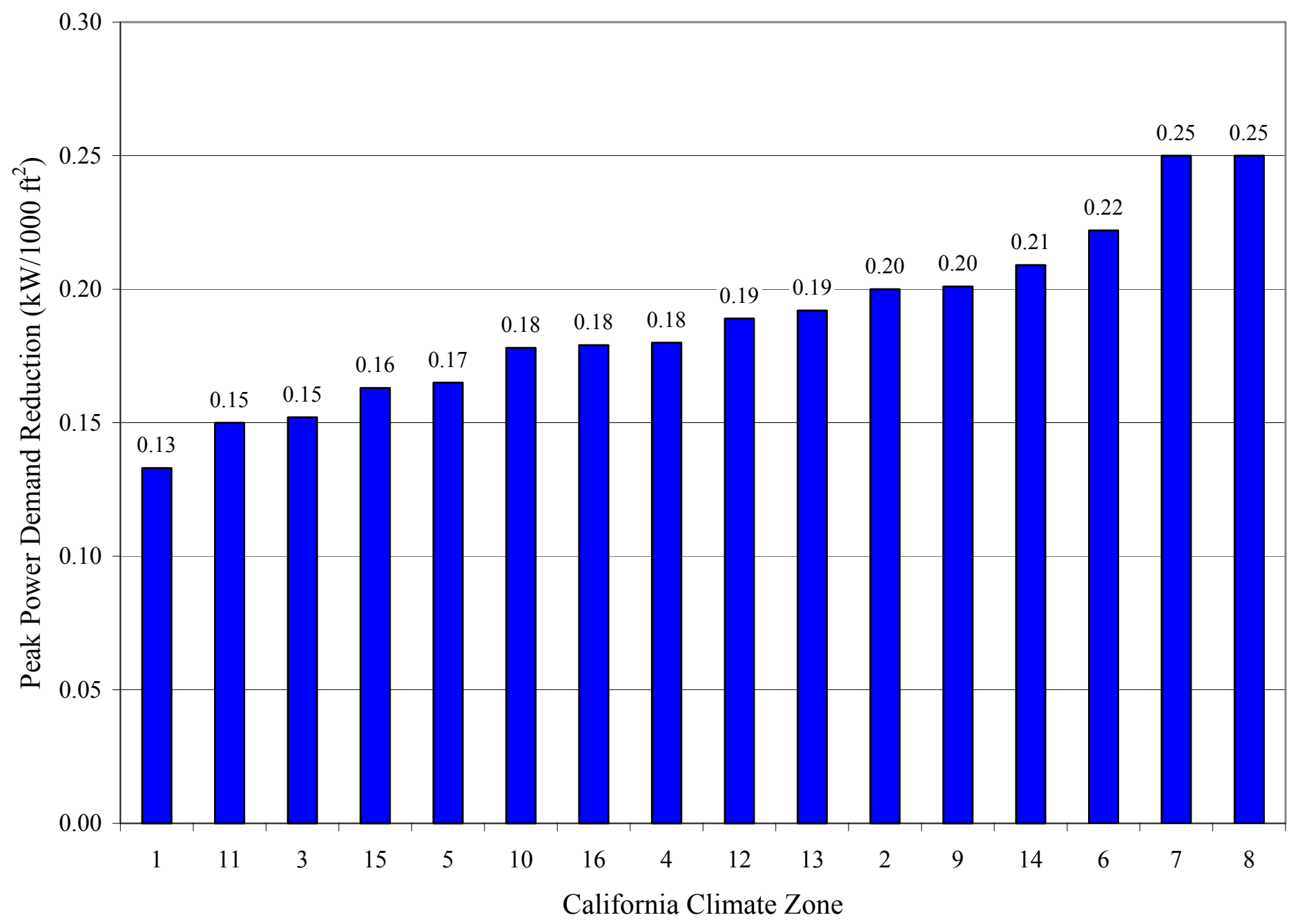

Figure 5. Annual peak electric power demand reduction $\left(\mathrm{kW} / 1000 \mathrm{ft}^{2}\right)$ by California climate zone, simulated for a prototypical Title 24 building with a cool roof. 


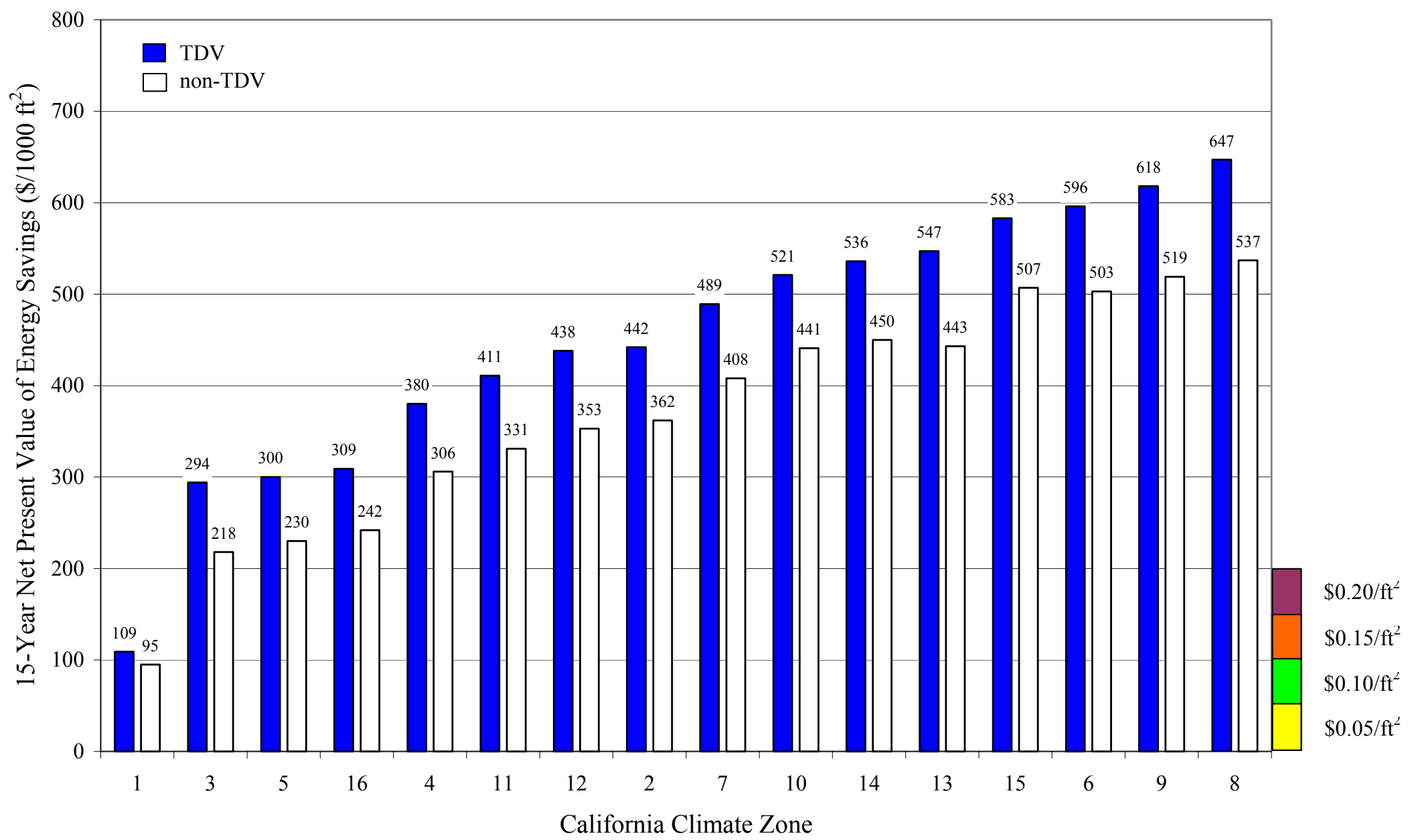

Figure 6. 15-year net present value (NPV) of energy savings (\$/1000 ft²) by California climate zone, simulated for a prototypical Title 24 building with a cool roof. Savings are shown with and without time dependent valuation (TDV). 


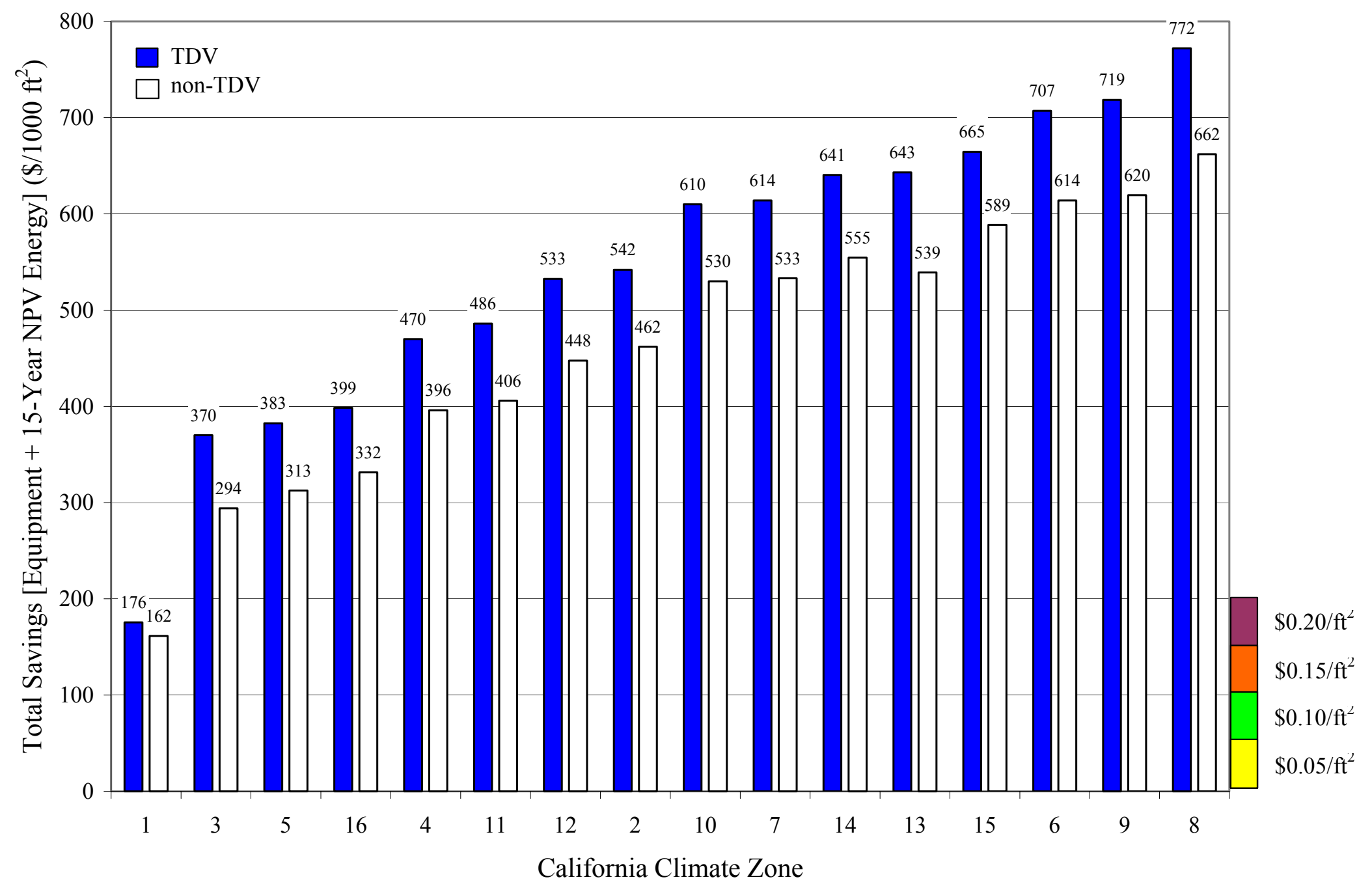

Figure 7. Total savings (cooling equipment savings + 15-year NPV of energy savings) in $\$ / 1000 \mathrm{ft}^{2}$ by California climate zone, simulated for a prototypical Title 24 building with a cool roof. Savings are shown with and without time dependent valuation (TDV). 


\section{Cost Effectiveness for New Construction}

The 15-year NPV of cool-roof energy savings for a Title 24 prototypical new building with an EER10 air conditioner ${ }^{11}$ ranged from 0.11 to $0.65 \$ / \mathrm{ft}^{2}$ (average $\$ 0.45 / \mathrm{ft}^{2}$ ) [1.18 to $7.00 \$ / \mathrm{m}^{2}$ (average $\$ 4.84 / \mathrm{m}^{2}$ )] with time dependent valuation (TDV), and from 0.10 to $0.54 \$ / \mathrm{ft}^{2}$ (average $\$ 0.37 / \mathrm{ft}^{2}$ ) [1.08 to $5.81 \$ / \mathrm{m}^{2}$ (average $\$ 3.98 / \mathrm{m}^{2}$ )] without TDV. Cost savings from downsizing cooling equipment ranged from 0.67 to $1.25 \$ / \mathrm{ft}^{2}$ (average $\$ 0.94 / \mathrm{ft}^{2}$ ) [7.21 to $13.5 \$ / \mathrm{m}^{2}$ (average $\$ 10.1 / \mathrm{m}^{2}$ )]. Thus, total savings (equipment + energy) ranged from 0.18 to $0.77 \$ / \mathrm{ft}^{2}$ (average $\$ 0.55 / \mathrm{ft}^{2}$ ) [1.94 to $8.29 \$ / \mathrm{m}^{2}$ (average $\$ 5.92 / \mathrm{m}^{2}$ )] with TDV, and from 0.16 to $0.66 \$ / \mathrm{ft}^{2}$ (average $\$ 0.47 / \mathrm{ft}^{2}$ ) [1.72 to $7.10 \$ / \mathrm{m}^{2}$ (average $\$ 5.06 / \mathrm{m}^{2}$ )] without TDV. With or without TDV, total savings in all climates except zone 1 exceeded $\$ 0.20 / \mathrm{ft}^{2}\left[\$ 2.15 / \mathrm{m}^{2}\right]$. Since the typical cost premium for a cool roof is 0.00 to $0.20 \$ / \mathrm{ft}^{2}$ [0.00 to $2.15 \$ / \mathrm{m}^{2}$ ], cool roofs are expected to be cost effective in climate zones 2 through 16 . Cool roofing materials with cost premiums not exceeding $\$ 0.18 / \mathrm{ft}^{2}$ [\$1.94/ $\left.\mathrm{m}^{2}\right]$ are expected to be cost effective in climate zone 1.

\section{Statewide Projected Savings for New Construction}

The database of 990 sample buildings indicates that there are $0.46 \mathrm{Mft}^{2}$ of daytime-conditioned roof area per $\mathrm{Mft}^{2}$ of California NRNC floor area [0.46 $\mathrm{km}^{2}$ per $\left.\mathrm{km}^{2}\right]$ (Table 8). Using the average Commission estimate of $158 \mathrm{Mft}^{2}$ [14.7 km²] of annual NRNC, $72 \mathrm{Mft}^{2}$ [6.7 km²] of statewide daytime-conditioned roof area are added each year to California's NR building stock, of which 46 $\mathrm{Mft}^{2}\left[4.3 \mathrm{~km}^{2}\right]$ are low-sloped and not yet cool. This yields the following annual values for statewide NRNC:

- electricity savings of $14.8 \mathrm{GWh}$;

- natural gas deficit of 199 ktherm [21.0 TJ];

- source energy savings of 132 GBTU [139 TJ];

- peak power demand savings ${ }^{12}$ of $9.2 \mathrm{MW}$;

\footnotetext{
11 The 2001 Title 24 requirements for air-cooled, electrically operated unitary air conditioners are EER10.3 for units sized 65-135 kBTU/h [19-40 kW], and EER9.7 for units sized 135-240 kBTU/h [40-70 kW]. EER10 was chosen as an average. Since cooling electricity use and peak power demand scale inversely with efficiency, values for buildings with more efficient cooling units can be calculated by multiplying the cooling electricity use and peak power demand results in Table 7, Table 8, and Table 9 by $10 / n$, where $n$ is the higher EER.
}

12 "Annual" power savings refers to reductions in the annual need for power plant construction. 
Table 8. Daytime-conditioned nonresidential (NR) roof area; also, simulated cool-roof annual energy, peak demand, cooling equipment cost, and net present value (NPV) savings (energy only, and total = energy + equipment), with and without time dependent valuation (TDV). Values are shown in each California climate zone, and totaled statewide. Calculations are normalized per applicable $\mathrm{Mft}^{2}$ (Mft ${ }^{2}$ app) of NR new construction in California, where applicable means having a noncool, low-sloped roof.

\begin{tabular}{|c|c|c|c|c|c|c|c|c|c|c|}
\hline \multirow[b]{2}{*}{$\begin{array}{c}\text { climate } \\
\text { zone }\end{array}$} & \multirow{2}{*}{$\begin{array}{c}\text { Mft }^{2} \\
\text { daytime- } \\
\text { condioned } \\
\text { roof areal } \\
\text { Mft }^{2}{ }^{\text {app }} \\
\end{array}$} & \multicolumn{3}{|c|}{ annual energy } & \multicolumn{2}{|c|}{ peak power } & \multicolumn{2}{|c|}{ TDV NPV } & \multicolumn{2}{|c|}{ non-TDV NPV } \\
\hline & & $\begin{array}{l}\mathrm{MWh} / \\
\mathrm{Mft}^{2}{ }_{\text {app }}\end{array}$ & 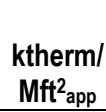 & $\begin{array}{l}\text { source } \\
\text { MBTU/ } \\
\text { Mft }^{2} \text { app }\end{array}$ & $\begin{array}{c}\mathbf{k W /} \\
\mathrm{Mft}^{2}{ }_{\text {app }}\end{array}$ & $\begin{array}{c}\mathbf{k} \text { \$equip/ } \\
\mathrm{Mft}^{2}{ }_{\text {app }}\end{array}$ & $\begin{array}{c}\text { k\$energy/ } \\
\text { Mft }^{2}{ }^{\text {app }}\end{array}$ & $\begin{array}{l}\mathbf{k} \$ \text { totall } \\
\mathrm{Mft}^{2}{ }_{\text {app }}\end{array}$ & $\begin{array}{c}\mathbf{k} \text { \$energy/ } \\
\mathrm{Mft}^{2}{ }_{\text {app }}\end{array}$ & $\begin{array}{c}\mathbf{k} \$ \text { total } \\
\mathrm{Mft}{ }^{2} \text { app }\end{array}$ \\
\hline 1 & 0.001 & 0.1 & -0.01 & 0.3 & 0.1 & 0.1 & 0.1 & 0.2 & 0.1 & 0.2 \\
\hline 2 & 0.019 & 5.7 & -0.11 & 47.3 & 3.9 & 1.9 & 8.6 & 10.5 & 7.0 & 9.0 \\
\hline 3 & 0.041 & 7.6 & -0.20 & 57.6 & 6.3 & 3.1 & 12.2 & 15.3 & 9.0 & 12.2 \\
\hline 4 & 0.051 & 12.5 & -0.21 & 106.9 & 9.2 & 4.6 & 19.4 & 23.9 & 15.6 & 20.2 \\
\hline 5 & 0.006 & 1.1 & -0.03 & 8.6 & 0.9 & 0.5 & 1.7 & 2.2 & 1.3 & 1.8 \\
\hline 6 & 0.061 & 23.7 & -0.25 & 217.9 & 13.6 & 6.8 & 36.5 & 43.2 & 30.8 & 37.6 \\
\hline 7 & 0.036 & 11.2 & -0.09 & 105.6 & 9.0 & 4.5 & 17.5 & 22.0 & 14.6 & 19.1 \\
\hline 8 & 0.041 & 16.8 & -0.15 & 156.7 & 10.1 & 5.1 & 26.3 & 31.3 & 21.8 & 26.9 \\
\hline 9 & 0.041 & 16.4 & -0.18 & 149.1 & 8.2 & 4.1 & 25.1 & 29.2 & 21.1 & 25.2 \\
\hline 10 & 0.046 & 15.7 & -0.17 & 143.9 & 8.2 & 4.1 & 24.0 & 28.1 & 20.3 & 24.4 \\
\hline 11 & 0.010 & 2.6 & -0.05 & 21.7 & 1.4 & 0.7 & 4.0 & 4.7 & 3.2 & 3.9 \\
\hline 12 & 0.057 & 16.3 & -0.30 & 136.8 & 10.8 & 5.4 & 25.0 & 30.4 & 20.1 & 25.5 \\
\hline 13 & 0.019 & 6.7 & -0.10 & 59.0 & 3.7 & 1.8 & 10.5 & 12.3 & 8.5 & 10.3 \\
\hline 14 & 0.017 & 5.9 & -0.08 & 53.0 & 3.5 & 1.8 & 9.1 & 10.8 & 7.6 & 9.4 \\
\hline 15 & 0.010 & 3.8 & -0.02 & 37.6 & 1.6 & 0.8 & 5.9 & 6.7 & 5.1 & 5.9 \\
\hline 16 & 0.001 & 0.2 & -0.01 & 1.2 & 0.2 & 0.1 & 0.3 & 0.4 & 0.2 & 0.3 \\
\hline Total & 0.457 & 146 & -2.0 & 1303 & 91 & 45 & 226 & 271 & 186 & 232 \\
\hline
\end{tabular}

- equipment savings of $\$ 4.6 \mathrm{M}$;

- TDV NPV energy savings of $\$ 22.9 \mathrm{M}$;

- TDV total savings (equipment + NPV energy) of $\$ 27.5 \mathrm{M}$;

- non-TDV NPV energy savings of $\$ 18.9 \mathrm{M}$; and

- non-TDV total savings (equipment + NPV energy) of \$23.5M (Table 9).

\section{Statewide Projected Savings for Roof Replacement}

Savings were not precisely calculated for roof replacements because data regarding the extent of roof replacements by climate zone are not currently available. Assuming that the statewide savings for roof replacements would be roughly proportional to the ratio of replacement $(\$ 4.1 \mathrm{~B})$ to new (\$1.4B) roof sales reported by Western Roofing Siding and Insulation in 1999 (Dodson 1999), statewide projected savings from roof replacement would be 2.9 times those from new construction. This yields the following annual values for statewide replacement of warm roofs by cool roofs:

- electricity savings of $43.0 \mathrm{GWh}$; 
- natural gas deficits of 577 ktherm [60.9 TJ];

- source energy savings of 383 GBTU [404 TJ];

- peak power demand savings of $26.7 \mathrm{MW}$;

- equipment savings of $\$ 13.3 \mathrm{M}$;

- TDV NPV energy savings of $\$ 66.4 \mathrm{M}$;

- TDV total savings (equipment + NPV energy) of \$79.7M;

- non-TDV NPV energy savings of \$54.8M; and

- non-TDV total savings (equipment + NPV energy) of \$68.1M.

Savings may actually be higher, since cooling equipment in older buildings tends to be less efficient than that required in new construction.

\section{Measured Building Energy Savings}

Cool roofs typically yielded measured summertime daily air-conditioning savings and peak demand reductions of 10 to $30 \%$, though values have been as low as $2 \%$ and as high as $40 \%$. For example:

- Konopacki et al. (1998b) measured daily summer air-conditioning savings of 6.3, 3.6, and $0.4 \mathrm{kWh} / 1000 \mathrm{ft}^{2}\left[68,39\right.$, and $\left.4 \mathrm{Wh} / \mathrm{m}^{2}\right](18,13$, and 2\%) for three California nonresidential buildings-two medical offices in Davis and Gilroy and a retail store in San Jose. Corresponding demand reductions were 0.31, 0.22, and $0.15 \mathrm{~kW} / 1000 \mathrm{ft}^{2}\left[3.3,2.4,1.6 \mathrm{~W} / \mathrm{m}^{2}\right](12,8$, and 9\%). Estimated annualized air conditioning savings were 590, 340, and $60 \mathrm{kWh} / 1000 \mathrm{ft}^{2}[6.4,3.7$, and $0.6 \mathrm{kWh} / \mathrm{m}^{2}$ ], assuming an aged solar reflectance of 0.55 .

- Hildebrandt et al. (1998) measured daily air-conditioning savings (annual savings / number of cooling days per year) of 2.1, 4.1, and $2.3 \mathrm{kWh} / 1000 \mathrm{ft}^{2}\left[23,44\right.$, and $\left.25 \mathrm{Wh} / \mathrm{m}^{2}\right](17,26$, and $39 \%)$ in an office, a museum and a hospice in Sacramento. Estimated annualized air-conditioning

Table 9. Typical Commission-projected statewide annual nonresidential new construction (NRNC) floor area; estimated statewide annual daytime-conditioned NRNC roof area; and simulated statewide coolroof annual energy, peak demand, cooling equipment cost, and net present value (NPV) savings (energy only, and total = energy + equipment), with and without time dependent valuation (TDV). Estimates are shown for all nonresidential new-construction (NRNC), and for the subset of NRNC to which cool-roof savings is applicable (that having a noncool, low-sloped roof).

\begin{tabular}{|c|c|c|c|c|c|c|c|c|c|c|c|}
\hline & & & & inual ene & & & power & TDV & & non-TL & NPV \\
\hline & area & roof area & GWh & Mtherm & GBTU & MW & M\$equip & M\$energy & M\$total & M\$energy & M\$total \\
\hline All NRNC & 158 & 72.3 & 23.2 & -0.311 & 206 & 14.4 & 7.2 & 35.8 & 43.0 & 29.5 & 36.7 \\
\hline $\begin{array}{c}\text { Applicable } \\
\text { NRNC }\end{array}$ & 101 & 46.3 & 14.8 & -0.199 & 132 & 9.2 & 4.6 & 22.9 & 27.5 & 18.9 & 23.5 \\
\hline
\end{tabular}


savings were 120, 240, and $200 \mathrm{kWh} / 1000 \mathrm{ft}^{2}$ [1.3, 2.6, and $2.1 \mathrm{kWh} / \mathrm{m}^{2}$ ], assuming an aged solar reflectance of 0.55 .

- Konopacki and Akbari (2001) estimated daily cooling energy savings of $3.6 \mathrm{kWh} / 1000 \mathrm{ft}^{2}$ [39 Wh/m²] (11\%) and peak power reduction of $0.35 \mathrm{~kW} / 1000 \mathrm{ft}^{2}\left[3.8 \mathrm{~W} / \mathrm{m}^{2}\right](14 \%)$ in a large retail store in Austin, TX. Estimated annualized air-conditioning savings were $630 \mathrm{kWh} / 1000 \mathrm{ft}^{2}$ [6.8 kWh/m²], assuming an aged solar reflectance of 0.55 .

- Parker et al. (1998b) measured daily energy savings of $4.1 \mathrm{kWh} / 1000 \mathrm{ft}^{2}$ [44 Wh/m²] (25\%) and a peak power reduction of $0.56 \mathrm{~kW} / 1000 \mathrm{ft}^{2}\left[6.0 \mathrm{~W} / \mathrm{m}^{2}\right](30 \%)$ for a school building in Florida. Estimated annualized air-conditioning savings were $440 \mathrm{kWh} / 1000 \mathrm{ft}^{2}\left[4.7 \mathrm{kWh} / \mathrm{m}^{2}\right]$, assuming an aged solar reflectance of 0.55 .

The California building studies (Konopacki et al. 1998b; Hildebrandt et al. 1998) are detailed in Table 10. The annualized measured energy savings were within or exceed the range of simulated annual kWh savings, except in the case of the retail store in San Jose. In that exceptional case, the simulation overpredicted measured savings because the building was modeled without an attic radiant barrier that was present in the actual building. In general, differences between simulated and measured savings can be attributed to one or more of the following:

- inadequacy of DOE-2.1E's model of attic radiation exchange;

- actual weather vs. typical weather used in simulations;

- actual building operation vs. Title 24's standard operating assumptions;

- actual roof insulation vs. Title 24's prescriptive requirement;

- actual air-conditioner equipment efficiency vs. Title 24's prescriptive requirements; and

- actual change in solar reflectance vs. 0.35 increase used in simulations. 
Table 10. Measured energy savings in six California nonresidential buildings (Konopacki et al. 1998b; Hildebrandt et al. 1998).

\begin{tabular}{|c|c|c|c|c|c|c|}
\hline & $\begin{array}{c}\text { Davis } \\
\text { medical office }\end{array}$ & $\begin{array}{c}\text { Gilroy } \\
\text { medical office }\end{array}$ & $\begin{array}{l}\text { San Jose } \\
\text { retail store }\end{array}$ & $\begin{array}{l}\text { Sacramento } \\
\text { office }\end{array}$ & $\begin{array}{l}\text { Sacramento } \\
\text { museum }\end{array}$ & $\begin{array}{l}\text { Sacramento } \\
\text { hospice }\end{array}$ \\
\hline \multicolumn{7}{|l|}{ Roof } \\
\hline Area $\left(1000 \mathrm{ft}^{2}\right)$ & 31.7 & 23.8 & 32.9 & 24.6 & 4.9 & 6.0 \\
\hline Type & built-up & built-up & built-up & 4-ply with capsheet & built-up gravel & $\begin{array}{l}\text { composite } \\
\text { shingle/ } \\
\text { flat built-up }\end{array}$ \\
\hline Material & $\begin{array}{l}\text { asphalt capsheet } \\
\text { with light gray } \\
\text { granules }\end{array}$ & $\begin{array}{l}\text { asphalt capsheet } \\
\text { with light gray } \\
\text { granules }\end{array}$ & $\begin{array}{l}\text { asphalt capsheet } \\
\text { with tan granules }\end{array}$ & $\begin{array}{l}\text { asphalt capsheet } \\
\text { with light gray } \\
\text { granules }\end{array}$ & $\begin{array}{l}\text { asphalt capsheet } \\
\text { with light gray } \\
\text { granules }\end{array}$ & $\begin{array}{l}\text { asphalt } \\
\text { capsheet } \\
\text { with tan } \\
\text { granules }\end{array}$ \\
\hline Insulation & $\mathrm{R}-8$ rigid & $\mathrm{R}-19$ fiberglass & radiant barrier & $\mathrm{R}-19$ & none & $\mathrm{R}-11$ \\
\hline Structure & metal deck & wood deck & wood deck & metal deck & wood deck & wood deck \\
\hline Plenum Type & return plenum & $\begin{array}{l}\text { ventilated } \\
\text { plenum }\end{array}$ & $\begin{array}{l}\text { ventilated } \\
\text { plenum }\end{array}$ & return plenum & ventilated plenum & $\begin{array}{l}\text { ventilated } \\
\text { plenum }\end{array}$ \\
\hline Ceiling Type & tiles & tiles & tiles & tiles & tiles & tiles \\
\hline Pre-Coating Condition & $\begin{array}{l}25 \% \text { granule loss } \\
\text { and bubbling }\end{array}$ & $\begin{array}{l}25 \% \text { granule loss } \\
\text { and cracking }\end{array}$ & $\begin{array}{l}25 \% \text { granule loss } \\
\text { and cracking }\end{array}$ & $\begin{array}{l}25 \% \text { granule loss } \\
\text { and bubbling }\end{array}$ & $\begin{array}{l}25 \% \text { granule loss } \\
\text { and cracking }\end{array}$ & $\begin{array}{l}25 \% \text { granule } \\
\text { loss and } \\
\text { cracking }\end{array}$ \\
\hline $\begin{array}{c}\text { Pre-Coating } \\
\text { Solar Reflectance }\end{array}$ & 0.24 & 0.25 & 0.16 & 0.24 & 0.25 & 0.16 \\
\hline $\begin{array}{l}\text { Post-Coating } \\
\text { Solar Reflectance } \\
\text { After } 1 \text { Year }\end{array}$ & 0.60 & 0.60 & 0.60 & 0.60 & 0.60 & 0.60 \\
\hline $\begin{array}{c}\text { Degraded } \\
\text { (Weathered) } \\
\text { Solar Reflectance }\end{array}$ & 0.55 & 0.55 & 0.55 & 0.55 & 0.55 & 0.55 \\
\hline \multicolumn{7}{|l|}{ SUPPLY DUCT } \\
\hline Insulation & none & $\mathrm{R}-4.6$ & R-2 & none & $\mathrm{R}-4.6$ & $\mathrm{R}-2$ \\
\hline Location & conditioned space & plenum & plenum & conditioned space & plenum & plenum \\
\hline \multicolumn{7}{|l|}{ RESULTS } \\
\hline $\begin{array}{l}\text { Measured Daily A/C } \\
\text { Energy Savings } \\
\text { (kWh/1000 ft²/day) }\end{array}$ & 6.3 & 3.6 & 0.4 & 2.1 & 4.1 & 2.3 \\
\hline Cooling Days/Year & 110 & 110 & 165 & 165 & 165 & 165 \\
\hline $\begin{array}{c}\text { Degraded Annual A/C } \\
\text { Energy Savings } \\
\left(\mathrm{kWh} / 1000 \mathrm{ft}^{2} / \mathrm{yr}\right)\end{array}$ & 590 & 340 & 60 & 120 & 240 & 200 \\
\hline $\begin{array}{l}\text { Degraded Peak } \\
\text { Demand Reduction } \\
\left(\mathrm{kW} / 1000 \mathrm{ft}^{2}\right)\end{array}$ & 0.31 & 0.22 & 0.15 & $\mathrm{n} / \mathrm{a}$ & $\mathrm{n} / \mathrm{a}$ & $\mathrm{n} / \mathrm{a}$ \\
\hline
\end{tabular}




\section{Summary and Conclusions}

Reviews of low-sloped roofing technologies and the western-state roofing market indicate that cool options are available for nearly all low-sloped roofs, including the three dominant products: built-up roofing, modified bitumen, and single-ply membrane. We qualify roofs as cool if they have a minimum thermal emittance of 0.75 and a minimum solar reflectance of 0.70 . A roof with an initial thermal emittance ( $\varepsilon_{\text {initial }}$ ) less than 0.75 can qualify as cool if it has a minimum initial solar reflectance not less than $0.70+0.34 \times\left(0.75-\varepsilon_{\text {initial }}\right)$. Buildings with roofs that do not meet prescriptive requirements may comply with Title 24 via an "overall-envelope" approach, or via a performance approach. The former applies only to buildings with non-metal roofs, while the latter may be used for all buildings.

Substituting a cool roof for a noncool roof decreases cooling electricity use, peak cooling power demand, and cooling-equipment capacity requirements, while increasing heating energy consumption. Cool roofs can also lower the ambient air temperature, slowing ozone formation and increasing human comfort. Cool roofs may also last longer than noncool roofs, reducing solid waste and demand for landfill. The increased need for heating energy may yield a net increase in local emissions if buildings are heated with natural gas and cooled with electricity.

DOE-2.1E building energy simulations indicate that the use of a cool roof on a prototypical California Title 24 nonresidential building with a low-sloped roof yields (to two significant figures) average annual cooling energy savings of $300 \mathrm{kWh} / 1000 \mathrm{ft}^{2}\left[3.2 \mathrm{kWh} / \mathrm{m}^{2}\right]$, average annual natural gas deficits of 4.9 therm/1000 $\mathrm{ft}^{2}\left[5.6 \mathrm{MJ} / \mathrm{m}^{2}\right]$, average source energy savings of $2.6 \mathrm{MBTU} / 1000 \mathrm{ft}^{2}$ [30 MJ/m²], and average peak power demand savings of $0.19 \mathrm{~kW} / 1000 \mathrm{ft}^{2}\left[2.1 \mathrm{~W} / \mathrm{m}^{2}\right]$. The 15 -year net present value (NPV) of energy savings averages $\$ 450 / 1000 \mathrm{ft}^{2}\left[\$ 4.90 / \mathrm{m}^{2}\right]$ with time dependent valuation (TDV), and $\$ 370 / 1000 \mathrm{ft}^{2}$ without TDV [\$4.00/ $\mathrm{m}^{2}$ ]. When cost savings from downsizing cooling equipment are included, the average total savings (15-year NPV + equipment savings) rise to $\$ 550 / 1000 \mathrm{ft}^{2}\left[\$ 5.90 / \mathrm{m}^{2}\right]$ with TDV, and $\$ 470 / 1000 \mathrm{ft}^{2}\left[\$ 5.00 / \mathrm{m}^{2}\right]$ without TDV.

Statewide projected annual savings (deficits) for new construction are 15 GWh electricity, (200) ktherm [(21) TJ] natural gas, 130 GBTU [140 TJ] source energy, 9.2 MW peak power demand (reduction in annual need for power plant construction), and \$4.6M equipment. With TDV, NPV energy savings are $\$ 23 \mathrm{M}$, and total savings are $\$ 28 \mathrm{M}$; without TDV, NPV energy savings are $\$ 19 \mathrm{M}$, and total savings are $\$ 24 \mathrm{M}$. For roof replacement, statewide projected annual savings (deficits) are 43 GWh electricity, (580) ktherm [(61) TJ] natural gas, 380 GBTU [400 TJ] source energy, 27 MW peak power demand (reduction in annual need for power plant construction), and \$13M equipment. 
With TDV, NPV energy savings are $\$ 66 \mathrm{M}$, and total savings are $\$ 80 \mathrm{M}$; without TDV, NPV energy savings are $\$ 55 \mathrm{M}$, and total savings are $\$ 62 \mathrm{M}$.

Total savings ranged from 0.18 to $0.77 \$ / \mathrm{ft}^{2}$ [1.90 to $8.30 \$ / \mathrm{m}^{2}$ ] with TDV, and from 0.16 to $0.66 \$ / \mathrm{ft}^{2}$ [1.70 to $7.10 \$ / \mathrm{m}^{2}$ ] without TDV, across California's 16 climate zones. The typical cost premium for a cool roof is 0.00 to $0.20 \$ / \mathrm{ft}^{2}$ [0.00 to $2.20 \$ / \mathrm{m}^{2}$ ]. Cool roofs with premiums up to $\$ 0.20 / \mathrm{ft}^{2}\left[\$ 2.20 / \mathrm{m}^{2}\right]$ are expected to be cost effective in climate zones 2 through 16; those with premiums not exceeding $\$ 0.18 / \mathrm{ft}^{2}\left[\$ 1.90 / \mathrm{m}^{2}\right.$ ] are expected to be also cost effective in climate zone 1. Hence, this study recommends that the year-2005 Title 24 code for nonresidential buildings with low-sloped roofs include a cool-roof prescriptive requirement in all California climate zones.

The analysis and recommendations in this study were directed only at nonresidential buildings with low-sloped roofs. In the future, it might make sense to extend the analysis and propose modifications to California Title 24 energy efficiency standards for all other building types: nonresidential buildings with high-sloped roofs, residential buildings with low-sloped roofs, and residential buildings with highsloped roofs.

Many California homes equipped with air conditioning are in coastal or transitional climates where mechanical cooling is used only on the hottest days of the year. In such cases, the installation of a cool roof can potentially obviate the need to operate or even install air conditioning. This could make analysis of a residential-building code change proposal of great interest to California.

\section{Bibliography and Other Research}

- Akbari, H., M. Pomerantz, and H. Taha. 2001. Cool surfaces and shade trees to reduce energy use and improve air quality in urban areas. Solar Energy 70(3):295-310. This review paper highlights the environmental benefits of reflective roofs, reflective pavements, and shade trees.

- Akbari, H., S. Konopacki, and D. Parker. 2000. Updates on revision to ASHRAE Standard 90.2: including roof reflectivity for residential buildings. In ACEEE 2000 Summer Study on Energy Efficiency in Buildings 1:1-11 (Pacific Grove, CA; August). Washington, DC: American Council for an Energy Efficient Economy. This report summarizes the technical efforts in support of modifying ASHRAE standards for new residential buildings to offer credit (lower roof-insulation requirements) for reflective roofs.

- Akbari, H. and L. Rainer. 2000. Measured energy savings from the application of reflective roofs in 3 AT\&T regeneration buildings. LBNL-47075. Berkeley, CA: Lawrence Berkeley National Laboratory. This study summarizes the results of a monitoring project where the effects of a white roof coating were measured in three small buildings housing telecommunication equipment. 
- Akbari, H., S. Konopacki, and M. Pomerantz. 1999. Cooling energy savings potential of reflective roofs for residential and commercial buildings in the United States. Energy 24:391407. This paper summarizes the results of a comprehensive simulation study to quantify the cooling energy savings of reflective roofs.

- Akbari, H. (editor). 1998a. ASHRAE Technical Data Bulletin 14(2) - Energy Savings of Reflective Roofs. Atlanta, GA: American Society of Heating, Refrigerating, and Air-Conditioning Engineers. This ASHRAE technical bulletin is a collection of six articles presented in two ASHRAE symposia discussing the benefits of cool roofs.

- Akbari, H. 1998b. Cool roofs save energy. ASHRAE Transactions 104(1B):783-788. This review paper highlights the costs and benefits of reflective roofs.

- Akbari, H. and S. Konopacki. 1998. The impact of reflectivity and emissivity of roofs on building cooling and heating energy use. In Thermal Performance of the Exterior Envelopes of Buildings VII (Miami, FL; December). Atlanta, GA: American Society of Heating, Refrigerating, and AirConditioning Engineers. It is postulated that if a roof with high solar reflectance reduces a building's cooling energy use during the summer, then a roof with low thermal emissivity can save heating energy use during the winter. This study summarizes the results of a parametric simulation analysis investigating the effects of roof reflectance and thermal emittance on building heating and cooling energy use in hot and cold climates.

- Akbari, H., L. Gartland, and S. Konopacki. 1998a. Measured energy savings of light-colored roofs: results from three California demonstration sites. In 1998 ACEEE Summer Study on Energy Efficiency in Buildings 3:1-12 (Pacific Grove, CA; August). Washington, DC: American Council for an Energy Efficient Economy. This paper summarizes measured cooling energy savings from the application of white roof coatings on three nonresidential buildings in California.

- Akbari, H., S. Konopacki, D. Parker, B. Wilcox, C. Eley, and M. Van Geem. 1998b. Calculations in support of SSP90.1 for reflective roofs. ASHRAE Transactions 104(1):976-987. This report summarizes the technical efforts in support of modifying ASHRAE standards for new nonresidential buildings to offer credit (reduced ceiling insulation requirements) for reflective roofs.

- Akbari, H., S. Bretz, H. Taha, D. Kurn, and J. Hanford. 1997. Peak power and cooling energy savings of high-albedo roofs. Energy and Buildings 25(2):117-126 - Special Issue on Urban Heat Islands and Cool Communities. This paper provides a summary of measured cooling energy savings in three buildings in Sacramento, CA.

- Akbari, H., R. Levinson, and P. Berdahl. 1996. ASTM standards for measuring solar reflectance and infrared emittance of construction materials and comparing their steady-state surface temperature. In 1996 ACEEE Summer Study on Energy Efficiency in Buildings 1:1-10 (Pacific Grove, CA; August). Washington, DC: American Council for an Energy Efficient Economy. This study summarizes the efforts in development of ASTM standard E 1918 for in-situ measurement of the solar reflectance of roofs. 
- Akbari, H., A. Rosenfeld, and H. Taha. 1995. Cool construction materials offer energy savings and help reduce smog. ASTM Standardization News 23(11):32-37 (November). This article provides an overview of the benefits of cool roofing materials.

- Akbari, H., S.E. Bretz, J.W. Hanford, D.M. Kurn, B.L. Fishman, H.G. Taha, and W. Bos. 1993. Monitoring peak power and cooling energy savings of shade trees and white surfaces in the Sacramento Municipal Utility District (SMUD) service area: data analysis, simulations and results. LBL-34411. Berkeley, CA: Lawrence Berkeley National Laboratory. This report summarizes the monitored savings in three residential and two nonresidential buildings.

- ASHRAE. 2001. ASHRAE Standard 90.1-2001: Energy Standard for Buildings Except Low-Rise Residential Buildings, SI Edition. Atlanta, GA: American Society of Heating, Refrigerating, and Air-Conditioning Engineers. This document provides detailed standard guidelines for the design of energy-efficient nonresidential buildings.

- ASTM. 1998a. ASTM C 1371-98: standard test method for determination of emittance of materials near room temperature using portable emissometers. In Annual Book of ASTM Standards, Vol. 04.06. Philadelphia, PA: American Society for Testing and Materials. This laboratory method can be used to measure the thermal emittance of a small area $\left(5 \mathrm{~cm}^{2}\right)$ of roofing.

- ASTM. 1998b. ASTM E 1980-98: standard practice for calculating solar reflectance index of horizontal and low-sloped opaque surfaces. In Annual Book of ASTM Standards, Vol. 04.12. Philadelphia, PA: American Society for Testing and Materials. This practice details the calculation of the Solar Reflectance Index, a metric that compares the temperature of a roof to that of a standard white roof and that of a standard black roof.

- ASTM. 1998c. ASTM G 159-98: standard tables for reference solar spectral irradiance at air mass 1.5: direct normal and hemispherical for a $37^{\circ}$ tilted surface. In Annual Book of ASTM Standards, Vol. 14.04. Philadelphia, PA: American Society for Testing and Materials. This table of solar spectral irradiances can be combined with ASTM E 903-96: standard test method for solar absorptance, reflectance, and transmittance using integrating spheres to compute the solar reflectance of a small area $\left(5 \mathrm{~cm}^{2}\right)$ of roofing from measurements of its spectral reflectance.

- ASTM. 1997. ASTM E 1918-97: standard test method for measuring solar reflectance of horizontal and low-sloped surfaces in the field. In Annual Book of ASTM Standards, Vol. 14.12. Philadelphia, PA: American Society for Testing and Materials. This field method uses a pyranometer to measure the solar reflectance of a large area $\left(10 \mathrm{~m}^{2}\right)$ of roofing.

- ASTM. 1996. ASTM E 903-96: standard test method for solar absorptance, reflectance, and transmittance using integrating spheres. In Annual Book of ASTM Standards, Vol. 12.02. Philadelphia, PA: American Society for Testing and Materials. This laboratory method for measurement of spectral reflectance can be combined with ASTM G 159-98: standard tables for reference solar spectral irradiance at air mass 1.5: direct normal and hemispherical for a $37^{\circ}$ 
tilted surface to compute the solar reflectance of a small area $\left(5 \mathrm{~cm}^{2}\right)$ of roofing from measurements of its spectral reflectance.

- ASTM. 1971. ASTM E 408-71: standard test methods for total normal emittance of surfaces using inspection-meter techniques. In Annual Book of ASTM Standards, Vol. 15.03. Philadelphia, PA: American Society for Testing and Materials. This standard describes the measurement of the total normal emittance of a surface by means of portable inspection-meter instruments.

- BCAP. 2002. Status of State Energy Codes, January/February. Washington, DC: Building Codes Assistance Project. Online at http://www.bcap-energy.org . This newsletter details the residential and nonresidential energy codes adopted in each U.S. state.

- Berdahl, P. and S. Bretz. 1997. Preliminary survey of the solar reflectance of cool roofing materials. Energy and Buildings 25(2):149-158 - Special Issue on Urban Heat Islands and Cool Communities. This technical paper provides insights on the spectral properties of roofing materials and on how cool roofing materials can be developed.

- Berhe, A., R. Levinson, and H. Akbari. 2003. Effects of weathering and cleaning on the solar reflectance of roofing membranes (in progress). Berkeley, CA: Lawrence Berkeley National Laboratory. This report will detail the extents to which brushing, rinsing, and washing restore the solar reflectances of soiled roofing membranes to their initial values.

- BESG (Building Energy Simulation Group). 1990. Overview of the DOE-2 building energy analysis program, version 2.1D. LBNL-19735, Rev. 1. Berkeley, CA: Lawrence Berkeley National Laboratory. This document contains a complete description of the DOE2.1D building model, including summaries of all commands and keywords.

- Bretz, S. and H. Akbari. 1997. Long-term performance of high-albedo roof coatings. Energy and Buildings 25(2):159-167 - Special Issue on Urban Heat Islands and Cool Communities. Data for long-term performance of reflective roofs are provided and analyzed in this article.

- Bretz, S., H. Akbari, and A. Rosenfeld. 1997. Practical issues for using high-albedo materials to mitigate urban heat islands. Atmospheric Environment 32(1):95-101. This study discusses some of the issues related to practical application of cool roofs, such as color and the degradation of solar reflectance.

- Builder. 1995. Roofing. Builder Magazine, April, 55-57.

- CEC. 2000. California energy demand, 2000-2010. P200-00-002. Sacramento, CA: California Energy Commission. This document includes California floor space stock projections by building type for the years 2000-2010.

- CEC. 2001. 2001 energy efficiency standards for residential and nonresidential buildings. P400-01-024. Sacramento, CA: California Energy Commission. This document sets forth energy 
efficiency standards for residential and nonresidential buildings in California effective 1 June 2001.

- Dodson, M. 1999. Low-slope market: western low-slope roofing market to hit \$5.5 billion in 1999. Western Roofing Insulation and Siding, November/December, 66-67. This article describes the year-1999 new and replacement low-sloped roofing markets in 14 western U.S. states.

- Dodson, M. 2001. The growing western roofing market. Western Roofing Insulation and Siding. Online at http://www.westernroofing.net . This magazine compiles an annual description of the nonresidential and residential roofing markets in 14 western U.S. states. Annual market descriptions are currently published on the magazine's website, but not in the magazine itself.

- Eley Associates. 2002. Life cycle cost methodology: 2005 California building energy efficiency standards. P400-02-009. Sacramento, CA: California Energy Commission. This document details the calculation of the life cycle cost of an energy efficiency measure with and without time dependent valuation of energy.

- Freedonia Group. 1997. Roofing to 2001. Report 886 (May). Cleveland, OH: The Freedonia Group.

- Hildebrandt, E., W. Bos, and R. Moore. 1998. Assessing the impacts of white roofs on building energy loads. ASHRAE Technical Data Bulletin 14(2):28-36. Atlanta, GA: American Society of Heating, Refrigerating, and Air-Conditioning Engineers. This document reports measured daily air conditioning savings in an office, a museum, and a hospice with reflective roofs in Sacramento.

- Hoffner, Douglas. 2002. Personal communication. Douglas Hoffner of the Roofing Contractors Association of California estimates that of the approximately 6000 licensed roofing contractors statewide, about 5000 are active.

- Konopacki, S. and H. Akbari. 2001. Measured energy savings and demand reduction from a reflective roof membrane on a large retail store in Austin. LBNL-47149. Berkeley, CA: Lawrence Berkeley National Laboratory. This document reports daily energy savings and peak power reduction in a large retail store in Austin, TX yielded by the installation of a solar-reflective roofing membrane.

- Konopacki, S. and H. Akbari. 2000. Energy savings calculations for heat island reduction strategies in Baton Rouge, Sacramento and Salt Lake City. In 2000 ACEEE Summer Study on Energy Efficiency in Buildings 9:215-226 (Pacific Grove, CA; August). Washington, DC: American Council for an Energy Efficient Economy. This paper summarizes the results of a detailed simulation study to quantify the direct and indirect energy saving potentials of cool roofs and shade trees in three cities.

- Konopacki, S. and H. Akbari. 1998. Simulated impact of roof surface solar absorptance, attic, and duct insulation on cooling and heating energy use in single-family new residential buildings. LBNL-41834. Berkeley, CA: Lawrence Berkeley National Laboratory. This report 
details the effort to modify ASHRAE standards for new residential buildings to account for the effects of roof solar reflectance.

- Konopacki, S., H. Akbari, and D. Parker. 1998a. Trade-off between cool roofs and attic insulation in new single-family residential buildings. In 1998 ACEEE Summer Study on Energy Efficiency in Buildings 1:159-170 (Pacific Grove, CA; August). Washington, DC: American Council for an Energy Efficient Economy. This paper summarizes some efforts to modify ASHRAE standards for new residential buildings to account for the effects of roof solar reflectance.

- Konopacki, S., L. Gartland, H. Akbari, and L. Rainer. 1998b. Demonstration of energy savings of cool roofs. LBNL-40673. Berkeley, CA: Lawrence Berkeley National Laboratory. This report summarizes measured cool-roof energy savings data in three California nonresidential buildings.

- Konopacki, S., H. Akbari, M. Pomerantz, S. Gabersek, and L. Gartland. 1997. Cooling energy savings potential of light-colored roofs for residential and commercial buildings in 11 U.S. metropolitan areas. LBL-39433. Berkeley, CA: Lawrence Berkeley National Laboratory. This study reports DOE-2 simulations of cool-roof energy savings in various U.S. cities.

- Lease, C. 2002. Personal communication. Roofing contractor Craig Lease (Stockton Roofing Company, Stockton, CA) reports that he uses high pressure water (140 gal/1000 ft² [5.7 L/m²]) and baking soda $\left(0.5 \mathrm{lb} / 1000 \mathrm{ft}^{2}\left[2.4 \mathrm{~g} / \mathrm{m}^{2}\right]\right)$ to wash roofs and neutralize acidic pollutants.

- Lufkin, P.S. and A.J. Pepitone. 1997. The Whitestone Building Maintenance and Repair Cost Reference 1997, 3rd Annual Edition (March). Seattle, WA: Whitestone Research.

- NRCA. 2000. 2000-2001 Annual Market Survey. Rosemont, IL: National Roofing Contractors Association. This survey of about 2000 U.S. roofing contractors details roofing sales by product and region.

- NRCA (National Roofing Contractors Association). 1998. Data on life expectancies of roofing materials used on homes. Roofing/Siding/Insulation, November, 44. The National Roofing Contractors Association frequently surveys its members about various aspects of commercial and residential roofing.

- Parker, D., J. Huang, S. Konopacki, L. Gartland, J. Sherwin, and L. Gu. 1998a. Measured and simulated performance of reflective roofing systems in residential buildings. ASHRAE Transactions 104(1B):963-975. Measured data for over 12 residential buildings are discussed, analyzed and compared to a calibrated simulation model.

- Parker, D., J. Sherwin, and J. Sonne. 1998b. Measured performance of a reflective roofing system in a Florida commercial building. ASHRAE Technical Data Bulletin 14(2):7-12. Atlanta, GA: American Society of Heating, Refrigerating, and Air-Conditioning Engineers. This article details energy savings for a school. 
- Parker, D., J. Sonne, and J. Sherwin. 1997. Demonstration of cooling savings of light colored roof surfacing in Florida commercial buildings: retail strip mall. FSEC CR-964-97. Cocoa, FL: Florida Solar Energy Center. This article details energy savings measured in a strip-mall.

- Pomerantz, M., H. Akbari, P. Berdahl., S. J. Konopacki, and H. Taha. 1999. Reflective surfaces for cooler buildings and cities. Philosophical Magazine B 79(9):1457-1476. This paper is a technical review of the benefits associated with cool roofs.

- RLW. 1999. Non-residential new construction baseline study. Study 3511. Sonoma, CA: RLW Analytics. Online at http://www.rlw.com . This database of nonresidential new construction (NRNC) describes 990 sample California nonresidential buildings, including each building's floor area, roof area, climate zone, building type, and "case weight" factor indicating how representative the sample building is of California NRNC.

- Rosenfeld, A., H. Akbari, S. Bretz, B. Fishman, D. Kurn, D. Sailor, and H. Taha. 1995. Mitigation of urban heat islands: material, utility programs, updates. Energy and Buildings 22:255-265. This study develops a model in which the combined value of the direct and indirect energy and airquality savings potentials for Los Angeles, CA is estimated to exceed $\$ 0.5 \mathrm{~B}$ per year.

- Somasundaram, S., P.R. Armstrong, D.B. Belzer, S.C. Gaines, D.L. Hadley, S. Katipamula, D.L. Smith, and D.W. Winiarski. 2000. Screening analysis for EPACT-covered commercial HVAC and water-heating equipment. PNNL-13232. Richland, WA: Pacific Northwest National Laboratory. This document includes data on the per-kW cost of cooling equipment.

- Taha, H. 2001. Potential impacts of climate change on tropospheric ozone in California: a preliminary episodic modeling assessment of the Los Angeles Basin and the Sacramento Valley. LBNL-46695. Berkeley, CA: Lawrence Berkeley National Laboratory. The climate and airquality effects of heat island reduction measures are quantified and discussed.

- Taha, H., S.-C. Chang, and H. Akbari. 2000. Meteorological and air quality impacts of heat island mitigation measures in three U.S. cities. LBL-44222. Berkeley, CA: Lawrence Berkeley National Laboratory. This paper summarizes the result of a detailed simulation study to quantify the direct and indirect ozone air quality savings potentials of cool roofs and shade trees for three cities.

- Taha, H., S. Konopacki, and S. Gabersek. 1999. Impacts of large-scale surface modifications on meteorological conditions and energy use: a 10-region modeling study. Theoretical and Applied Climatology 62:175-185. The paper summarizes the large-scale effects of heat-island-reduction measures on regional meteorology and air quality for 10 regions in the U.S.

- Winkelmann, F., B. Birdsall, W. Buhl, K. Ellington and A. Erdem. 1993. DOE-2 supplement version 2.1E. LBNL-34947. Berkeley, CA: Lawrence Berkeley National Laboratory. This document summarizes all commands and keywords in the DOE-2.1E Building Description Language, and contains materials supplementing DOE-2.1D. 


\section{Appendix A: \\ Requisite Reflectance Premium for a Low-Emittance Cool Roof}

Under typical daytime conditions, a low-emittance roof will be warmer than a high-emittance roof of equal solar reflectance. Thus, a low-emittance cool roof must be more reflective than a highemittance cool roof to achieve the same steady-state surface temperature.

Consider a high-emittance (HE) cool roof surface of solar reflectance $\rho_{\mathrm{HE}}$ and thermal emittance $\varepsilon_{\mathrm{HE}}$. Neglecting conduction of heat into the building, the high-emittance roof's steady-state surface temperature $T_{\mathrm{HE}}$ is determined by equating its solar heat gain to its radiative and convective heat losses:

$$
\left(1-\rho_{\mathrm{HE}}\right) I=\varepsilon_{\mathrm{HE}} \sigma\left(T_{\mathrm{HE}}^{4}-T_{\mathrm{sky}}^{4}\right)+h_{c}\left(T_{\mathrm{HE}}-T_{\mathrm{air}}\right)
$$

where $I$ is insolation [W m-2], $\sigma=5.6685 \times 10^{-8} \mathrm{~W} \mathrm{~m}^{-2} \mathrm{~K}^{-4}$ (the Stefan-Boltzmann constant), $h_{c}$ is the convection coefficient [ $\left.\mathrm{W} \mathrm{m}^{-2} \mathrm{~K}^{-1}\right], T_{\text {sky }}$ is the sky temperature [K], and $T_{\text {air }}$ is the air temperature [K]. The insolation, convection coefficient, and temperatures of sky and air may be taken from the moderate-wind standard conditions specified by ASTM E 1980-98 ("standard practice for calculating solar reflectance index of horizontal and low-sloped opaque surfaces"): $I=1000 \mathrm{~W} \mathrm{~m}^{-2}$, $h_{c}=12 \mathrm{~W} \mathrm{~m}^{-2} \mathrm{~K}^{-1}, T_{\text {sky }}=300 \mathrm{~K}$, and $T_{\text {air }}=310 \mathrm{~K}$ (ASTM 1998b). This energy balance may be solved numerically to determine the high-emittance cool roof temperature $T_{\mathrm{HE}}$.

We now wish to determine the minimum reflectance $\rho_{\mathrm{LE}}$ required of a low-emittance (LE) cool roof (emittance $\varepsilon_{\mathrm{LE}}$ ) so that its surface temperature does not exceed that of the high-emittance cool roof; i.e., $T_{\mathrm{LE}} \leq T_{\mathrm{HE}}$.

The energy balance for the low-emittance roof has the same form as that for the high-emittance roof:

$$
\left(1-\rho_{\mathrm{LE}}\right) I=\varepsilon_{\mathrm{LE}} \sigma\left(T_{\mathrm{LE}}^{4}-T_{\mathrm{sky}}^{4}\right)+h_{c}\left(T_{\mathrm{LE}}-T_{\mathrm{air}}\right)
$$

Both Eqs. (2) and (3) can be rearranged to relate reflectance to emittance:

$$
\rho_{\mathrm{HE}}=\left[1+h_{c}\left(T_{\mathrm{HE}}-T_{\mathrm{air}}\right) / I\right]-\left[\sigma\left(T_{\mathrm{HE}}^{4}-T_{\mathrm{sky}}^{4}\right) / I\right] \varepsilon_{\mathrm{HE}}
$$

and

$$
\rho_{\mathrm{LE}}=\left[1+h_{c}\left(T_{\mathrm{LE}}-T_{\text {air }}\right) / I\right]-\left[\sigma\left(T_{\mathrm{LE}}^{4}-T_{\text {sky }}^{4}\right) / I\right] \varepsilon_{\mathrm{LE}} .
$$


When the LE and HE roofs are at the same temperature $T_{\text {cool }}$ (i.e., $T_{\mathrm{LE}}=T_{\mathrm{HE}}=T_{\text {cool }}$ ), we can subtract Eq. (4) from Eq. (5) to obtain

$$
\rho_{\mathrm{LE}}-\rho_{\mathrm{HE}}=\left[\sigma\left(T_{\mathrm{cool}}^{4}-T_{\mathrm{sky}}^{4}\right) / I\right] \times\left(\varepsilon_{\mathrm{HE}}-\varepsilon_{\mathrm{LE}}\right) .
$$

Thus, if a low-emittance roof is to stay as cool as a high-emittance roof $\left(T_{\mathrm{LE}}=T_{\mathrm{HE}}=T_{\text {cool }}\right)$, the reflectance premium $\Delta \rho \equiv \rho_{\mathrm{LE}}-\rho_{\mathrm{HE}}$ required to compensate for the emittance deficit $\Delta \varepsilon \equiv \varepsilon_{\mathrm{HE}}-\varepsilon_{\mathrm{LE}}$ is

$$
\Delta \rho=f\left(T_{\text {cool }}\right) \times \Delta \varepsilon
$$

where

$$
f\left(T_{\text {cool }}\right) \equiv \sigma\left(T_{\text {cool }}^{4}-T_{\text {sky }}^{4}\right) / I
$$

If the reflectance premium exceeds that specified by Eq. (7), the low-emittance roof will be even cooler than the high-emittance roof.

Since roof reflectance typically changes with age (see p. 9), we need to specify an initial reflectance premium high enough for the aged LE roof to stay as cool as the aged $\mathrm{HE}$ cool roof. This requires two steps. First, we calculate an aged reflectance premium $\Delta \rho_{\text {aged }}$ based on the surface temperature of the aged $\mathrm{HE}$ cool roof, $T_{\text {cool,aged }}$. Then, we determine the necessary initial reflectance premium, $\Delta \rho_{\text {initial }}$, based on the aged reflectance premium.

Equation (1) on p. 9 postulates that the relationship between initial and aged roof reflectance is $\rho_{\text {aged }}=\rho_{0}+c\left(\rho_{\text {initial }}-\rho_{0}\right)$, where constants $\rho_{0}=0.2$ and $c=0.7$. Thus

$$
\rho_{\mathrm{HE}, \text { aged }}=\rho_{0}+c\left(\rho_{\mathrm{HE}, \text { initial }}-\rho_{0}\right) \text {. }
$$

We will assume that aging does not change emittance. ${ }^{13}$ We can rearrange Eq. (1) to relate initial reflectance to aged reflectance:

$$
\rho_{\text {initial }}=\frac{\rho_{\text {aged }}+(c-1) \rho_{0}}{c} .
$$

\footnotetext{
13 This assumption is not strictly true, but is used in the absence of data on the variation of roof emittance with age.
} 
From this we can relate the initial reflectance premium to the aged reflectance premium:

$$
\Delta \rho_{\text {initial }}=\frac{\Delta \rho_{\text {aged }}}{c}
$$

Thus, the premium in initial solar reflectance required to ensure that an aged LE roof stays as cool as an aged $\mathrm{HE}$ roof is

$$
\Delta \rho_{\text {initial }}=\frac{1}{c} \times f\left(T_{\text {cool,aged }}\right) \times \Delta \varepsilon_{\text {aged }} .
$$

\section{Example 1: New Cool Roof}

Consider a new high-emittance cool roof with solar reflectance $\rho_{\mathrm{HE}}=0.70$ and thermal emittance $\varepsilon_{\mathrm{HE}}=0.75$. Its surface temperature will be $T_{\text {cool }}=324.4 \mathrm{~K}\left(124.3^{\circ} \mathrm{F}\right)$, yielding $f\left(T_{\text {cool }}\right)=0.169$. The surface temperature of a new low-emittance cool roof will not exceed that of the new high-emittance cool roof so long as

$$
\Delta \rho \geq 0.169 \times \Delta \varepsilon
$$

Thus, the minimum solar reflectance required for a new low-emittance cool roof is

$$
\rho_{\mathrm{LE}} \geq \rho_{\mathrm{HE}}+f\left(T_{\mathrm{cool}}\right) \times\left(\varepsilon_{\mathrm{HE}}-\varepsilon_{\mathrm{LE}}\right)=0.70+0.169 \times\left(0.75-\varepsilon_{\mathrm{LE}}\right) .
$$

A new roof with an emittance of 0.20 (e.g., a bare metal roof) would need a minimum solar reflectance of 0.79 to qualify as cool. As a limiting case, the minimum solar reflectance required for a new zero-emittance cool roof would be 0.83 .

\section{Example 2: Aged Cool Roof}

Consider a high-emittance cool roof with initial solar reflectance $\rho_{\mathrm{HE}, \text { initial }}=0.70$ and initial thermal emittance $\varepsilon_{\mathrm{HE} \text {,initial }}=0.75$. We calculate its aged reflectance from Eq. (9) as $\rho_{\mathrm{HE} \text {,aged }}=0.55$. The surface temperature of the aged high-emittance roof will be $T_{\text {cool,aged }}=332.8 \mathrm{~K}\left(139.3^{\circ} \mathrm{F}\right)$, yielding $f\left(T_{\text {cool,aged }}\right)=0.236$. The surface temperature of an aged low-emittance cool roof will not exceed that of the aged high-emittance cool roof so long as the low-emittance cool roof has a minimum initial reflectance premium of

$$
\Delta \rho_{\text {initial }}=\frac{1}{c} \times f\left(T_{\text {cool,aged }}\right) \times \Delta \varepsilon_{\text {aged }}=\frac{10}{7} \times 0.236 \times \Delta \varepsilon_{\text {aged }}=0.337 \times \Delta \varepsilon_{\text {aged }} .
$$


Thus, the minimum initial solar reflectance required for a low-emittance cool roof is approximately

$$
\rho_{\mathrm{LE}, \text { initial }}=\rho_{\mathrm{HE}, \text { initial }}+\frac{1}{c} \times f\left(T_{\text {cool,aged }}\right) \times \Delta \varepsilon_{\text {aged }}=0.70+0.34 \times\left(0.75-\varepsilon_{\mathrm{LE}, \text { initial }}\right) .
$$

Here we have assumed that the low and high emittances do not change with age.

A roof with a emittance of 0.20 (e.g., a bare metal roof) would need a minimum initial solar reflectance of 0.89 to qualify as cool. This corresponds to an aged reflectance of 0.68 . As a limiting case, the minimum initial solar reflectance required for a zero-emittance cool roof would be 0.95 , corresponding to an aged reflectance of 0.72 .

We use Eq. (16) in the prescriptive requirement for low-emittance cool roof to ensure that the surface temperature of an aged low-emittance cool roof does not exceed that of an aged highemittance cool roof.

\section{Appendix B: Proposed Standards Language}

The proposed standards language modifies solar reflectance and thermal emittance requirements for low-sloped roofs on nonresidential buildings. Requirements for NR buildings with high-sloped roofs, high-rise residential buildings, and guest rooms of hotel/motel buildings are unchanged. Requirements for cool roofing products are revised to qualify low-emittance products that have exceptionally high solar reflectance, and to restrict the qualification of moderate-reflectance clay and concrete tiles to low-rise residential applications.

The proposed standards language prescribes for low-sloped roofs on NR buildings a minimum initial reflectance of 0.70 for roofs that have an initial emittance not less than 0.75 . Roofs that have an initial emittance $\varepsilon_{\text {initial }}$ less than 0.75 (e.g., those with metallic surfaces) must have a minimum initial solar reflectance of $0.70+0.34 \times\left(0.75-\varepsilon_{\text {initial }}\right)$. The reflectance requirement for lowemittance cool roofs is designed to ensure that the surface temperature of an aged low-emittance cool roof does not exceed that of an aged high-emittance cool roof (see Appendix A, p. 41).

The proposed language changes the standard and proposed heat gain equations in the overallenvelope approach. Standard buildings are to use an initial reflectance of 0.70 for all low-sloped roofs, which is then degraded to 0.55 for aging. The proposed buildings shall use the CRRC-certified values for initial reflectance (or a default value of 0.10 if a CRRC value is unavailable), which is then degraded for aging according to Eq. (1) on p. 9. 
The prescriptions for cool roofing products are revised to require a thermal-emittance-dependent minimum initial solar reflectance, and to delete product-specific reflectance and emittance requirements.

\section{Proposed Changes to 2001 California Energy Efficiency Standards for Residential and Nonresidential Buildings (January 3, 2001)}

Proposed additions are underlined and deletions are struck.

\section{Section 101 - Definitions and Rules of Construction}

COOL ROOF is a roofing material with high solar reflectance and high emittance high thermal emittance and high solar reflectance, or low thermal emittance and exceptionally high solar reflectance [cf. Section 143 (a)1], that reduces heat gain through the roof.

LOW-SLOPED ROOF is a roof that has a ratio of rise to run not exceeding 2:12.

\section{Section 118 - Mandatory Requirements for Insulation and Cool Roofs}

(f) Mandatory Requirements for Cool Roofs. Effective January 1, 2003, a A roof shall be considered a cool roof if the roofing product is certified and labeled according to requirements of Section 10113 and if the roofing product meets conditions 1 and 2 and, for liquid applied coating products, 3 below. Prior to January 1, 2003, manufacturer's published performance data shall be acceptable to show compliance with 1 or 2 and, for liquid applied roofing products, 3 .

1. Concrete tile (as defined in ASTM 655-99) and clay tile (as defined in ASTM C1167-96) roofing products shall have a minimum initial total solar reflectance of 0.40 when tested in accordance with ATSM E903 or E1918, and a minimum thermal emittance of 0.75 when tested in accordance with ASTME408.

2. All other roofing products shall have a minimum initial total solar reflectance of 0.70 when tested in accordance with ASTM E903 or E1918, and a minimum thermal emittance of 0.75 when tested in accordance with ASTM E408.

1. Roofing products that have initial thermal emittance not less than 0.75 when tested in accordance with ASTM E408 shall have a minimum initial solar reflectance of 0.70 when tested in accordance with ASTM E903 or E1918. 
Exception to Section 118(f)1: For low-rise residential buildings, concrete tile (as defined in ASTM C55-99) and clay tile (as defined in ASTM C1167-96) roofing products shall have a minimum initial total solar reflectance of 0.40 when tested in accordance with ATSM E903 or E1918, and a minimum thermal emittance of 0.75 when tested in accordance with ASTM E408.

2. Roofing products that have initial thermal emittance $\varepsilon_{\text {initial }}$ less than 0.75 when tested in accordance with ASTM E408, including but not limited to roofing products with metallic surfaces, must have a minimum initial solar reflectance of $0.70+0.34 \times\left(0.75-\varepsilon_{\text {initial }}\right)$ when tested in accordance with ASTM E903 or E1918.

3. Liquid applied roofing products shall be applied at a minimum dry mil thickness of 20 mils across the entire roof surface, and meet the minimum performance requirements of ASTM D6083-97 when tested in accordance with ASTM D6083-97 for the following key properties:

* Initial tensile strength

* Initial elongation

* Elongation after 1,000 hours accelerated weathering

* Permeance

* Accelerated weathering

\section{Section 143 - Prescriptive Requirements for Building Envelopes}

\section{(a) Envelope Component Approach.}

1. Exterior roofs and ceilings. Exterior roofs and ceilings shall have either an installed insulation Rvalue no less than, or an overall assembly U-factor no greater than, the applicable value in Table 1-H or 1-I.

For nonresidential buildings with low-sloped roofs (except high-rise residential buildings and guest rooms of hotel/motel buildings), roofs that have an initial thermal emittance not less than 0.75 shall have a minimum initial solar reflectance of 0.70 . Low-sloped exterior roofs that have an initial thermal emittance $\varepsilon_{\text {initial }}$ less than 0.75 , including but not limited to those with metallic surfaces, shall have a minimum initial solar reflectance of $0.70+0.34 \times\left(0.75-\varepsilon_{\text {initial }}\right)$.

There are no prescriptive solar reflectance or thermal emittance requirements for nonresidential buildings with high-sloped roofs, high-rise residential buildings, or guest rooms of hotel/motel buildings. 


\section{(b) Overall-Envelope Approach}

This method may be used only for roof surfaces with thermal emittance not less than 0.75 (typically non-metallic surfaces). It may not be used for roofs with metallic surfaces, including but not limited to bare metal, galvanized steel, and aluminum coating.

2. Overall heat gain

EQUATION (1-E)-STANDARD BUILDING HEAT GAIN EQUATION

$$
\begin{aligned}
H G_{s t d}= & \sum_{i=1}^{n W}\left(A_{W i} \times U_{W_{s t d}} \times T F_{i}\right) \\
& +\sum_{i=1}^{n F}\left(A_{F i} \times U_{F i_{s t d}} \times T F_{i}\right) \\
& +\sum_{i=1}^{n R}\left(A_{R i} \times U_{R i_{s d d}} \times T F_{i}\right) \\
& +\sum_{i=1}^{n G}\left(A_{G i} \times U_{G i_{s t d}} \times T F_{i}\right) \\
& +\sum_{i=1}^{n S}\left(A_{S i} \times U_{S i_{s t d}} \times T F_{i}\right) \\
& +\sum_{i=1}^{n G}\left(W F_{G i} \times A_{G i} \times R S H G_{G i_{s t d}}\right) \times S F \\
& +\sum_{i=1}^{n S}\left(W F_{S i} \times A_{S i} \times S H G C_{S i_{s t d}}\right) \times S F \\
& +\sum_{i=1}^{n R}\left(W F_{R i} \times A_{R i} \times U_{R i_{s d d}} \times \alpha_{R i_{s t d}}\left[1-\left(0.2+0.7 \times\left[\rho_{R i_{s t d}}-0.2\right]\right)\right]\right) \times S F
\end{aligned}
$$

$\alpha_{R_{s i d}}=A$ standard roof absorptivity of 0.70 for the corresponding $\underline{A_{R i}}$

$\rho_{R_{s i d}}=$ For low-sloped roofs on nonresidential buildings (excluding high-rise residential buildings and guest rooms in hotel/motel buildings), a standard initial roof reflectance of 0.70 for the corresponding $A_{R i}$; for other than low-sloped roofs on nonresidential buildings, for high rise residential buildings, and for guest rooms in hotel/motel buildings, a standard roof reflectance of

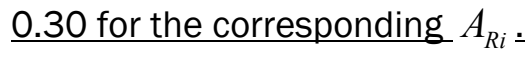




$$
\begin{aligned}
H G_{\text {prop }}= & \sum_{i=1}^{n W}\left(A_{W i} \times U_{W i_{\text {prop }}} \times T F_{i}\right) \\
& +\sum_{i=1}^{n F}\left(A_{F i} \times U_{F i_{\text {prop }}} \times T F_{i}\right) \\
& +\sum_{i=1}^{n R}\left(A_{R i} \times U_{R i_{\text {prop }}} \times T F_{i}\right) \\
& +\sum_{i=1}^{n G}\left(A_{G i} \times U_{G i_{\text {prop }}} \times T F_{i}\right) \\
& +\sum_{i=1}^{n S}\left(A_{S i} \times U_{S i_{\text {prop }}} \times T F_{i}\right) \\
& +\sum_{i=1}^{n G}\left(W F_{G i} \times A_{G i} \times R S H G_{G i_{\text {prop }}}\right) \times S F \\
& +\sum_{i=1}^{n S}\left(W F_{S i} \times A_{S i} \times S H G C_{S i_{\text {prop }}}\right) \times S F \\
& +\sum_{i=1}^{n R}\left(W F_{R i} \times A_{R i} \times U_{R i_{\text {prop }}} \times \alpha_{R i_{\text {prop }}}\left[1-\left(0.2+0.7 \times\left[\rho_{R i_{\text {prop }}}-0.2\right]\right)\right]\right) \times S F
\end{aligned}
$$

$\alpha_{R j_{\text {prop }}}=$ The applicable roof absorptivity for the corresponding $A_{R j}$. An absorptivity of 0.45 for cool roofs (as defined in Section 118). An absorptivity of 0.7 for all other roofs.

$\rho_{R j_{\text {prop }}}=$ the proposed initial reflectance for the corresponding $A_{R j}$. If no CRRC-certified value is available, the proposed reflectance will use the default value of 0.10 for low-sloped roofs on nonresidential buildings (excluding high-rise residential buildings and guest rooms in hotel/motel buildings), or 0.30 for other than low-sloped roofs on nonresidential buildings, for high-rise residential buildings, and for guest rooms in hotel/motel buildings.

Section 149 - Additions, Alterations, and Repairs to Existing Buildings That Will Be Nonresidential, High-Rise Residential, and Motel/Hotel Occupancies

\section{(b) Alterations}

1. Prescriptive Approach

A. Alterations to the building envelope shall: 
iii. Have, in the case of a roof, a solar reflectance and a thermal emittance meeting the requirements of Section 143(a)(1).

\section{Proposed ACM Language}

\section{Nonresidential Alternative Calculation Approval Method}

\subsubsection{Absorptance}

Modeling Rules for Proposed Design:

For roofs, qualifying cool roofs shall model an absorptance of 0.45 . All other roofs shall use the default value.

For nonresidential buildings with low-sloped roofs, the proposed design must receive user input for initial absorptance ( $\alpha_{\text {init }}$; absorptance $=1$ - reflectance). The ACM must calculate the corresponding aged value $\alpha_{\text {prop }}$ from the following equation:

$\alpha_{\text {prop }}=0.8+0.7 \times\left(\alpha_{\text {init }}-0.8\right)$

where $\alpha_{\text {init }}$ is the initial absorptance of the product either as rated by the CRRC or one of the defaults specified below.

Cool Roof Value: Roof $=0.45$

To qualify as a cool roof the roof must meet the requirements of Section 118 of the Standard, which states:

(a) Effective Januany 1, 2003, a roof shall be considered a cool roof if the roof is certified and tabeled according to requirements of Section 10 113 and if the roof meets conditions (1) or (2) below. Prior to Januany 1, 2003, manufacturer's published performance data shall be acceptable to show compliance with one of the following conditions.

(1) Roof of concrete tile (per ASTM C55-99) and clay tile (per ASTM C1167-96) require a minimum initial total solar reflectance of 0.40 when tested in accordance with ASTM E903 or E1918, and a minimum thermal emittance of 0.75 when tested in accordance with ASTM E408. 
(2) All other roofs require a minimum initial total solar reflectance of 0.70 when tested in accordance with ASTM E903 or E1918, and a minimum thermal emittance of 0.75 when tested in accordance with ASTM E408.

(3) Liquid applied roofing products shall be applied at a minimum dry mil thickness of 20 mils across the entire roof surface, and meet the minimum performance requirements of ASTM D6083-97 when tested in accordance with ASTM D6083 97 for the following key properties:

Initial Tensile Strength

Initial Elongation

Elongation After 1000 Hours Accelerated Weathering

Permeance

Accelerated Weathering

Default

Roof $=0.70$

Roof: for low-sloped roofs on nonresidential buildings (excluding high-rise residential buildings and guest rooms in hotel/motel buildings), 0.90; for other than low-sloped roofs on nonresidential buildings, for high-rise residential buildings, and for guest rooms in hotel/motel buildings, 0.70 Cool Roof Caution Warning on PERF 1 if a cool roof credit is claimed.

Modeling Rules for Reference Design (All):

For the reference method, the roof absorptance shall be modeled at 0.70 .

For the reference method for nonresidential buildings with low-sloped roofs (excluding high-rise residential buildings and guest rooms in hotel/motel buildings) the roof absorptance (1 reflectance) shall be modeled at 0.30 (reflectance 0.70 ). For the reference method for nonresidential buildings with other than low-sloped roofs, for high-rise residential buildings, and for guest rooms in hotel/motel buildings, the roof absorptance shall be modeled at 0.70 (reflectance $\underline{0.30)}$.

The ACM must calculate the corresponding aged value $\alpha_{\text {ref }}$ from the following equation.

$\underline{\alpha_{\text {ref }}}=0.8+0.7 \times\left(\alpha_{\text {std }}-\underline{0.8)}\right.$ 
where $\alpha_{\text {std }}$ is 0.30 for nonresidential buildings with low-sloped roofs or 0.70 for other nonresidential buildings, high-rise residential buildings and guest rooms in hotel/motel buildings

\subsubsection{Surface Emissivity Thermal Emittance}

Description: The ratio of radiation intensity from the construction assembly's opaque exterior surface to the radiation intensity at the same wavelength from a blackbody at the same temperature (hereafter, referred to as "emittance").

Tradeoffs: Neutral Yes

Modeling Rules for Proposed Design:

The proposed design shall model a surface emissivity of 0.90 .

For low-sloped roofs on nonresidential buildings (excluding high-rise residential buildings and guest rooms in hotel/motel buildings), the proposed design must receive user input for initial emittance. If no CRRC-certified value is available, a default value of 0.75 shall be used for non-metallic surfaces, and a default value of 0.20 shall be used for metallic surfaces, including but not limited to bare metal, galvanized steel, and aluminum coating.

For other than low-sloped roofs on nonresidential buildings, for high-rise residential buildings, and for guest rooms in hotel/motel buildings, the proposed design shall model a surface emittance of 0.90 .

Modeling Rules for Reference Design (All):

The surface emissivity of the reference design shall be the same as the surface emissivity of the proposed design.

For low-sloped roofs on nonresidential buildings (excluding high-rise residential buildings and guest rooms in hotel/motel buildings), the reference design shall be modeled at 0.75 .

For other than low-sloped roofs on nonresidential buildings and for roofs on high-rise residential buildings and guest rooms in hotel/motel buildings, the surface emittance of the reference design shall be the same as the surface emittance of the proposed design.

The emittance of each other opaque exterior surface shall be the same as that in the proposed design.

\subsubsection{Absorptance and Emittance}


Description: The ACM Compliance Documentation must describe how the user enters the value for the absorptance $(1$ - reflectance $)$ and the emittance.

ACM Compliance Documentation must explain that the ACM user can specify opaque exterior wall or roof/ceiling construction between 0.90 and 0.20 absorptance $(0.10$ and 0.80 reflectance $)$, and between 0.95 and 0.20 emittance, and that the program will print an exceptional condition on the PERF-1 whenever the absorptance $(1$ - reflectance $)$ is less than 0.50 for an opaque exterior partition. The ACM Compliance Documentation must explain what happens if the user does not specify an absorptance. The ACM Compliance documentation must explain to the user how to enter the values of cool roof and must describe the rating methods and installation criteria that are required for cool roofs. 